NUREG/CR-6601

ORNL/TM-13549

Neutron Exposure Parameters For The Dosimetry Capsule in The Heavy-Section Steel Irradiation Program Tenth Irradiation Series

Prepared by

I. Remec, C.A. Baldwin, F.B.K. Kam

Oak Ridge National Laboratory

Prepared for

U.S. Nuclear Regulatory Commission

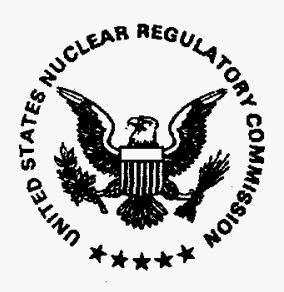




\section{AVAILABILITY NOTICE}

\section{Availability of Reference Materials Cited in NRC Publications}

NRC publications in the NUREG series, NRC regulations, and Title 10, Energy, of the Code of Federal Regulations, may be purchased from one of the following sources:

1. The Superintendent of Documents U.S. Government Printing Office

P.O. Box 37082

Washington, DC 20402-9328

$<$ http://www.access.gpo.gov/su_docs > $202-512-1800$

2. The National Technical Information Service Springfield, VA 22161-0002

<http://www.ntis.gov/ordernow>

$703-487-4650$

The NUREG series comprises (1) technical and administrative reports, including those prepared for international agreements, (2) brochures, (3) proceedings of conferences and workshops, (4) adjudications and other issuances of the Commission and Atomic Safety and Licensing Boards, and (5) books.

A single copy of each NRC draft report is available free, to the extent of supply, upon written request as follows:

\section{Address: Office of the Chief Information Officer Reproduction and Distribution \\ Services Section \\ U.S. Nuclear Regulatory Commission \\ Washington, DC 20555-0001 \\ E-mail: <GRW1@NRC.GOV>}

Facsimile: 301-415-2289

A portion of NRC regulatory and technical information is available at NRC's World Wide Web site:

$$
\text { <http://www.nrc.gov> }
$$

All NRC documents released to the public are available for inspection or copying for a fee, in paper, microfiche, or, in some cases, diskette, from the Public Document Room (PDR):
NRC Public Document Room

2121 L Street, N.W., Lower Level

Washington, DC 20555-0001

<http://www.nrc.gov/NRC/PDR/pdr1.htm>

$1-800-397-4209$ or locally $202-634-3273$

Microfiche of most NRC documents made publicly available since January 1981 may be found in the Local Public Document Rooms (LPDRs) located in the vicinity of nuclear power plants. The locations of the LPDRs may be obtained from the PDR (see previous paragraph) or through:

\section{<http://www.nrc.gov/NRC/NUREGS/ \\ SR1350/N9/lpdr/html>}

Publicly released documents include, to name a few, NUREG-series reports; Federal Register notices; applicant, licensee, and vendor documents and correspondence; NRC correspondence and internal memoranda; bulletins and information notices; inspection and investigation reports; licensee event reports; and Commission papers and their attachments.

Documents available from public and special technical libraries include all open literature items, such as books, journal articles, and transactions, Federal Register notices, Federal and State legislation, and congressional reports. Such documents as theses, dissertations, foreign reports and translations, and non-NRC conference proceedings may be purchased from their sponsoring organization.

Copies of industry codes and standards used in a substantive manner in the NRC regulatory process are maintained at the NRC Library, Two White Flint North, 11545 Rockville Pike, Rockville, MD 20852-2738. These standards are available in the library for reference use by the public. Codes and standards are usually copyrighted and may be purchased from the originating organization or, if they are American National Standards, from-
American National Standards Institute
11 West 42nd Street
New York, NY 10036-8002
$<$ http://www.ansi.org>
$212-642-4900$

\section{DISCLAIMER}

This report was prepared under an international cooperative agreement for the exchange of technical information. Neither the United States Government nor any agency thereof, nor any of their employees, makes any warranty, expressed or implied, or assumes any legal liability or responsibility for any third party's use, or the results of such use, of any information, apparatus, product, or process disclosed in this report, or represents that its use by such third party would not infringe privately owned rights. 


\section{Neutron Exposure Parameters For}

The Dosimetry Capsule in The

Heavy-Section Steel Irradiation

Program Tenth Irradiation Series

Manuscript Completed: March 1998

Date Published: October 1998

Prepared by

I. Remec, C.A. Baldwin, F.B.K. Kam

Oak Ridge National Laboratory

Managed by Lockheed Martin Energy Research Corp.

Oak Ridge, TN 37831-6285

E.M. Hackett, NRC Project Manager

Prepared for

Division of Engineering Technology

Office of Nuclear Regulatory Research

U.S. Nuclear Regulatory Commission

Washington, DC 20555-0001

NRC Job Code L1098 


\section{DISCLAIMER}

This report was prepared as an account of work sponsored by an agency of the United States Government. Neither the United States Government nor any agency thereof, nor any of their employees, make any warranty, express or implied, or assumes any legal liability or responsibility for the accuracy, completeness, or usefulness of any information, apparatus, product, or process disclosed, or represents that its use would not infringe privately owned rights. Reference herein to any specific commercial product, process, or service by trade name, trademark, manufacturer, or otherwise does not necessarily constitute or imply its endorsement, recommendation, or favoring by the United States Government or any agency thereof. The views and opinions of authors expressed herein do not necessarily state or reflect those of the United States Government or any agency thereof. 


\section{DISCLAIMER}

Portions of this document may be illegible in electronic image products. Images are produced from the best available original document. 


\section{Abstract}

This report describes the computational methodology for the least-squares adjustment of the dosimetry data from the HSSI 10.0D dosimetry capsule with neutronics calculations. It presents exposure rates at each dosimetry location for the neutron fluence greater than $1.0 \mathrm{MeV}$, fluence greater than $0.1 \mathrm{MeV}$, and displacements per atom. Exposure parameter distributions are also described in terms of threedimensional fitting functions. When fitting functions are used it is suggested that an uncertainty of $6 \%$ ( $1 \sigma)$ should be associated with the exposure rate values. The specific activity of each dosimeter at the end of irradiation is listed in the Appendix. 



\section{Contents}

Abstract $\ldots \ldots \ldots \ldots \ldots \ldots \ldots \ldots \ldots \ldots \ldots \ldots \ldots \ldots \ldots \ldots \ldots \ldots \ldots \ldots \ldots \ldots \ldots \ldots$

List of Figures $\ldots \ldots \ldots \ldots \ldots \ldots \ldots \ldots \ldots \ldots \ldots \ldots \ldots \ldots \ldots \ldots \ldots \ldots \ldots \ldots \ldots$

List of Tables $\ldots \ldots \ldots \ldots \ldots \ldots \ldots \ldots \ldots \ldots \ldots \ldots \ldots \ldots \ldots \ldots \ldots \ldots \ldots \ldots \ldots \ldots$

Acknowledgments $\ldots \ldots \ldots \ldots \ldots \ldots \ldots \ldots \ldots \ldots \ldots \ldots \ldots \ldots \ldots \ldots \ldots \ldots \ldots \ldots \ldots \ldots$

Foreword $\ldots \ldots \ldots \ldots \ldots \ldots \ldots \ldots \ldots \ldots \ldots \ldots \ldots \ldots \ldots \ldots \ldots \ldots \ldots \ldots \ldots \ldots \ldots$

Introduction $\ldots \ldots \ldots \ldots \ldots \ldots \ldots \ldots \ldots \ldots \ldots \ldots \ldots \ldots \ldots \ldots \ldots \ldots \ldots \ldots$

Methodology of the Analysis $\ldots \ldots \ldots \ldots \ldots \ldots \ldots \ldots \ldots \ldots \ldots \ldots \ldots \ldots \ldots \ldots \ldots \ldots$

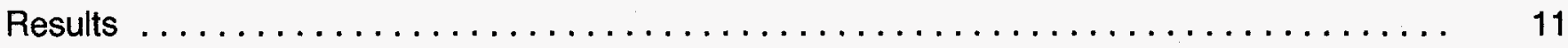

Conclusion $\ldots \ldots \ldots \ldots \ldots \ldots \ldots \ldots \ldots \ldots \ldots \ldots \ldots \ldots \ldots \ldots \ldots \ldots \ldots \ldots \ldots \ldots \ldots \ldots$

References $\ldots \ldots \ldots \ldots \ldots \ldots \ldots \ldots \ldots \ldots \ldots \ldots \ldots \ldots \ldots \ldots \ldots \ldots \ldots \ldots \ldots \ldots$

Appendix $\ldots \ldots \ldots \ldots \ldots \ldots \ldots \ldots \ldots \ldots \ldots \ldots \ldots \ldots \ldots \ldots \ldots \ldots \ldots \ldots \ldots$ 



\section{Figures}

1 Arrangement of the dosimeter locations inside the HSSI 10.0D capsule. Origin of the coordinate system is in the center of the front face of the capsule ............. 3

2 Location of the HSSI 10.0D capsule relative to the reactor core-horizontal cross section .... 4

3 Location of the HSSI 10.0D capsule relative to the reactor core-vertical cross section ...... 5

4 Thickness of materials between the core and the HSSI 10.0D

dosimetry capsule. Dimensions are in millimeters and inches within parentheses $\ldots \ldots \ldots \ldots 6$

A.1 Measured specific activities of the RDT dosimetry for the cycle 338B vs Z coordinate for (top) iron gradient wires and (bottom) cobalt gradient wires $\ldots \ldots \ldots \ldots \ldots 21$

A.2 Measured specific activities of the RDT dosimetry for the cycle 339B vs $Z$ coordinate for (top) iron gradient wires and (bottom) cobalt gradient wires

A.3 Measured specific activities of the RDT dosimetry for the cycle $340 \mathrm{~A}$ vs $Z$ coordinate for (top) iron gradient wires and (bottom) cobalt gradient wires

A.4 Normalized measured specific activities of the RDT dosimetry for the cycle $338 \mathrm{~B}$ vs $Z$ coordinate for (top) iron gradient wires and (bottom) cobalt gradient wires. Normalization is to the maximum value of 1.0 for each reaction and each RDT

A.5 Normalized measured specific activities of the RDT dosimetry for the cycle 339B vs Z coordinate for (top) iron gradient wires and (bottom) cobalt gradient wires. Values are normalized to the maximum value of 1.0 for each reaction and each RDT

A.6 Normalized measured specific activities of the RDT dosimetry for the cycle 340A vs $Z$ coordinate for (top) iron gradient wires and (bottom) cobalt gradient wires. Values are normalized to the maximum value of 1.0 for each reaction and each RDT 26 



\section{Tables}

1 Adjusted average fast fluence rates, $F_{E>1 \mathrm{Mev}}$, for cycles $338 \mathrm{~B}, 339 \mathrm{~B}$, and $340 \mathrm{~A}$

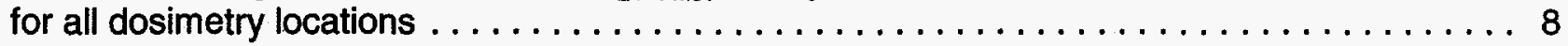

2 Adjusted average fast fluence rates, $F_{E>0.1 \mathrm{Mev}}$, for cycles $338 \mathrm{~B}, 339 \mathrm{~B}$, and $340 \mathrm{~A}$

for all dosimetry locations $\ldots \ldots \ldots \ldots \ldots \ldots \ldots \ldots \ldots \ldots \ldots \ldots \ldots \ldots$

3 Adjusted average displacement-per-atom (dpa) rates for cycles 338B, 339B,

and $340 \mathrm{~A}$ for all dosimetry locations . . . . . . . . . . . . . . . . . . . . . 10

4 Parameters from the three-dimensional fits of the exposure parameter rates $\ldots \ldots \ldots 11$

A.1 Activities of the dosimeters in the HSSI $10.0 \mathrm{D}$ dosimetry capsule $\ldots \ldots \ldots \ldots \ldots$

A.2 Irradiation history for $\mathrm{HSSI} 10.0 \mathrm{D}$ dosimetry capsule $\ldots \ldots \ldots \ldots \ldots \ldots \ldots \ldots \ldots$

A.3 Specific activities of the removable dosimeter tube (RDT) dosimeters in the HSSI 10.0D experiment at the end of irradiation (EOI) $\ldots \ldots \ldots \ldots \ldots \ldots \ldots \ldots \ldots \ldots \ldots \ldots \ldots \ldots$

A.4 Cycle-to-cycle comparison of specific activities of the removable dosimeter tube (RDT) dosimeters in the HSSI 10.0D experiment at the end of irradiation (EOI) . . . . . . . . . . 20

A.5 Comparison of the adjusted fast fluence rates, $F_{E>1 \mathrm{MeV}}$, with values obtained from three-dimensional (3-D) fit. Adjusted flux values are averages of the cycles 338B, 339B, and 340A . . . . . . . . . . . . . . . . . . . . . . . .

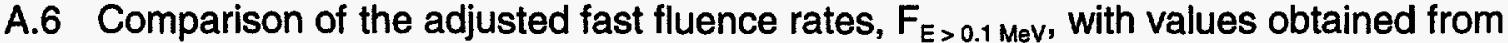
three-dimensional (3-D) fit. Adjusted flux values are averages of the cycles $338 \mathrm{~B}, 339 \mathrm{~B}$, and $340 \mathrm{~A}$

A.7 Comparison of the adjusted displacement-per-atom (dpa) rates with values obtained from three-dimensional (3-D) fit. Adjusted dpa rates are averages of the cycles 338B, 339B, and 340A 



\section{Acknowledgments}

The authors wish to thank llana Siman-Tov of the Oak Ridge National Laboratory (ORNL) Engineering Technology Division for providing engineering data and some of the sketches used in this report. Support for this work was provided by W. R. Corwin of the ORNL Metals and Ceramics Division, with programmatic funding from the U.S. Nuclear Regulatory Commission. This support was essential to accomplishing our objectives and is gratefully acknowledged. 


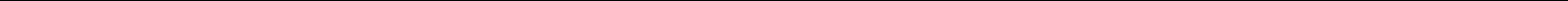




\section{Foreword}

The work reported here was performed at the Oak Ridge National Laboratory (ORNL) under the Heavy-Section Steel Irradiation (HSSI) Program, T. M. Rosseel, Program Manager. The program is sponsored by the Office of Nuclear Regulatory Research of the U.S. Nuclear Regulatory Commission (NRC). The technical monitor for the NRC is M. G. Vassilaros.

This report is designated HSSI Report 19. Reports in this series are listed below:

1. F. M. Haggag, W. R. Corwin, and R. K. Nanstad, Martin Marietta Energy Systems, Inc., Oak Ridge Natl. Lab., Oak Ridge, Tenn., Irradiation Effects on Strength and Toughness of Three-Wire Series-Arc Stainless Steel Weld Overlay Cladding, USNRC Report NUREG/CR-5511 (ORNL/TM-11439), February 1990.

2. L. F. Miller, C. A. Baldwin, F. W. Stallman, and F. B. K. Kam, Martin Marietta Energy Systems, Inc., Oak Ridge Natl. Lab., Oak Ridge, Tenn., Neutron Exposure Parameters for the Metallurgical Test Specimens in the Sixth Heavy-Section Steel Irradiation Series, USNRC Report NUREG/CR-5409 (ORNLTM-11267), March 1990.

3. S. K. Iskander, W. R. Corwin, and R. K. Nanstad, Martin Marietta Energy Systems, Inc., Oak Ridge Natl. Lab., Oak Ridge, Tenn., Results of Crack-Arrest Tests on Two Irradiated High-Copper Welds, USNRC Report NUREG/CR-5584 (ORNL/TM-11575), December 1990.

4. R. K. Nanstad and R. G. Berggren, Martin Marietta Energy Systems, Inc., Oak Ridge Natl. Lab., Oak Ridge, Tenn., Irradiation Effects on Charpy Impact and Tensile Properties of Low UpperShelf Welds, HSSI Series 2 and 3, USNRC Report NUREG/CR-5696 (ORNL/TM-11804), August 1991.

5. R. E. Stoller, Martin Marietta Energy Systems, Inc., Oak Ridge Natl. Lab., Oak Ridge, Tenn., Modeling the Influence of Irradiation Temperature and Displacement Rate on Radiation-Induced Hardening in Ferritic Steels, USNRC Report NUREG/CR5859 (ORNL/TM-12073), August 1992.

6. R. K. Nanstad, D. E. McCabe, and R. L. Swain, Martin Marietta Energy Systems, Inc., Oak Ridge Natl. Lab., Oak Ridge, Tenn., Chemical Composition $R T_{N D T}$ Determinations for Midland Weld WF-70, USNRC Report NUREG/CR-5914 (ORNL-6740), December 1992.

7. R. K. Nanstad, F. M. Haggag, D. E. McCabe, S. K. Iskander, K. O. Bowman, and B. H. Menke, Martin Marietta Energy Systems, Inc., Oak Ridge Natl. Lab., Oak Ridge, Tenn., Irradiation Effects on Fracture Toughness of Two High-Copper Submerged-Arc Welds, USNRC Report NUREG/CR-5913 (ORNL/TM-12156/V1), October 1992.

8. S. K. Iskander, W. R. Corwin, and R. K. Nanstad, Martin Marietta Energy Systems, Inc., Oak Ridge Natl. Lab., Oak Ridge, Tenn., Crack-Arrest Tests on Two Irradiated High-Copper Welds, USNRC Report NUREG/CR-6139 (ORNL/TM-12513), March 1994.

9. R. E. Stoller, Martin Marietta Energy Systems, Inc., Oak Ridge Natl. Lab., Oak Ridge, Tenn., $A$ Comparison of the Relative Importance of Copper Precipitates and Point Defects in Reactor Pressure Vessel Embrittlement, USNRC Report NUREG/CR-6231 (ORNLTM-6811), December 1994. 
10. D. E. McCabe, R. K. Nanstad, S. K. Iskander, and R. L. Swain, Martin Marietta Energy Systems, Inc., Oak Ridge Natl. Lab., Oak Ridge, Tenn., Unirradiated Material Properties of Midland Weld WF-70, USNRC Report NUREG/CR-6249 (ORNL/TM-12777), October 1994.

11. P. M. Rice and R. E. Stoller, Lockheed Martin Energy Systems, Oak Ridge Natl. Lab., Oak Ridge, Tenn., Microstructural Characterization of Selected AEAVUCSB Model FeCuMn Alloys, USNRC Report NUREG/CR-6332 (ORNLTM-12980), June 1996.

12. J. H. Giovanola and J. E. Crocker, SRI International, Fracture Toughness Testing with Cracked Round Bars: Feasibility Study, USNRC Report NUREG/CR-6342 (ORNL/SUB/94-DHK60), to be published.

13. F. M. Haggag and R. K. Nanstad, Lockheed Martin Energy Systems, Oak Ridge Natl. Lab., Oak Ridge, Tenn., Effects of Thermal Aging and Neutron Irradiation on the Mechanical Properties of Three-Wire Stainless Steel Weld Overlay Cladding, USNRC Report NUREG/CR-6363 (ORNL/TM-13047), May 1997.

14. M. A. Sokolov and D. J. Alexander, Lockheed Martin Energy Systems, Oak Ridge Natl. Lab., Oak Ridge, Tenn., An Improved Correlation Procedure for Subsize and Full-Size Charpy Impact Specimen Data, USNRC Report NUREG/CR-6379 (ORNL/TM-13088), March 1997.

15. S. K. Iskander and R. E. Stoller, Lockheed Martin Energy Research Corporation, Oak Ridge Natl. Lab., Oak Ridge, Tenn., Results of Charpy V-Notch Impact Testing of Structural Steel Specimens Irradiated at $\sim 30^{\circ} \mathrm{C}$ to $1 \times 10^{6}$ neutrons $/ \mathrm{cm}^{2}$ in a Commercial Reactor Cavity, USNRC Report NUREG/CR-6399 (ORNL-6886), April 1997.

16. S. K. Iskander, P. O. Milella, and A. Pini, Lockheed Martin Energy Research Corporation, Oak Ridge Natl. Lab., Oak Ridge, Tenn., Results of Crack-Arrest Tests on Irradiated A 503 Class 3 Steel, USNRC Report NUREG/CR-6447 (ORNL-6894), to be published.

17. P. Pareige, K. F. Russell, R. E. Stoller, and M. K, Miller, Lockheed Martin Energy Research Corporation, Oak Ridge Natl. Lab., Oak Ridge, Tenn., Influence of Long-Term Thermal Aging on the Microstructural Evolution of Nuclear Reactor Pressure Vessel Materials: An Atom Probe Study, USNRC Report NUREG/CR-6537 (ORNL/TM-13406), to be published.

18. I. Remec, C. A. Baldwin, and F. B. K. Kam, Lockheed Martin Energy Research Corporation, Oak Ridge, Natl., Lab., Oak Ridge, Tenn., Neutron Exposure Parameters for Capsule 10.05 in the Heavy-Section Steel Irradiation Program Tenth Irradiation Series, USNRC Report NUREG/CR6600 (ORNL/TM-13548), to be published.

19. This report.

The HSSI Program includes both follow-on and the direct continuation of work that was performed under the Heavy-Section Steel Technology (HSST) Program. Previous HSST reports related to irradiation effects in pressure vessel materials and those containing unirradiated properties of materials used in HSSI and HSST irradiation programs are tabulated below as a convenience to the reader.

C. E. Childress, Union Carbide Corp. Nuclear Div., Oak Ridge Natl. Lab., Oak Ridge, Tenn., Fabrication History of the First Two 12-in.-Thick A-533 Grade B, Class 1 Steel Plates of the HeavySection Steel Technology Program, ORNL-4313, February 1969. 
T. R. Mager and F. O. Thomas, Westinghouse Electric Corporation, PWR Systems Division, Pittsburgh, Pa., Evaluation by Linear Elastic Fracture Mechanics of Radiation Damage to Pressure Vessel Steels, WCAP-7328 (Rev.), October 1969.

P. N. Randall, TRW Systems Group, Redondo Beach, Calif., Gross Strain Measure of Fracture Toughness of Steels, HSSTP-TR-3, Nov. 1, 1969.

L. W. Loechel, Martin Marietta Corporation, Denver, Colo., The Effect of Testing Variables on the Transition Temperature in Steel, MCR-69-189, Nov. 20, 1969.

W. O. Shabbits, W. H. Pryle, and E. T. Wessel, Westinghouse Electric Corporation, PWR Systems Division, Pittsburgh, Pa., Heavy-Section Fracture Toughness Properties of A533 Grade B Class 1 Steel Plate and Submerged Arc Weldment, WCAP-7414, December 1969.

C. E. Childress, Union Carbide Corp. Nuclear Div., Oak Ridge Natl. Lab., Oak Ridge, Tenn., Fabrication History of the Third and Fourth ASTM A-533 Steel Plates of the Heavy-Section Steel Technology Program, ORNL-4313-2, February 1970.

P. B. Crosley and E. J. Ripling, Materials Research Laboratory, Inc., Glenwood, III., Crack Arrest Fracture Toughness of A533 Grade B Class 1 Pressure Vessel Steel, HSSTP-TR-8, March 1970.

F. J. Loss, Naval Research Laboratory, Washington, D.C., Dynamic Tear Test Investigations of the Fracture Toughness of Thick-Section Steel, NRL-7056, May 14, 1970.

T. R. Mager, Westinghouse Electric Corporation, PWR Systems Division, Pittsburgh, Pa., PostIrradiation Testing of 2T Compact Tension Specimens, WCAP-7561, August 1970.

F. J. Witt and R. G. Berggren, Union Carbide Corp. Nuclear Div., Oak Ridge Natl. Lab., Oak Ridge, Tenn., Size Effects and Energy Disposition in Impact Specimen Testing of ASTM A533 Grade B Steel, ORNLTM-3030, August 1970.

D. A. Canonico, Union Carbide Corp. Nuclear Div., Oak Ridge Natl. Lab., Oak Ridge, Tenn., Transition Temperature Considerations for Thick-Wall Nuclear Pressure Vessels, ORNLTM-3114, October 1970.

T. R. Mager, Westinghouse Electric Corporation, PWR Systems Division, Pittsburgh, Pa., Fracture Toughness Characterization Study of A533, Grade B, Class 1 Steel, WCAP-7578, October 1970.

W. O. Shabbits, Westinghouse Electric Corporation, PWR Systems Division, Pittsburgh, Pa., Dynamic Fracture Toughness Properties of Heavy-Section A533 Grade B Class 1 Steel Plate, WCAP-7623, December 1970.

C. E. Childress, Union Carbide Corp. Nuclear Div., Oak Ridge Natl. Lab., Oak Ridge, Tenn., Fabrication Procedures and Acceptance Data for ASTM A-533 Welds and a 10-in.-Thick ASTM A-543 Plate of the Heavy Section Steel Technology Program, ORNL-TM-4313-3, January 1971.

D. A. Canonico and R. G. Berggren, Union Carbide Corp. Nuclear Div., Oak Ridge Natl. Lab., Oak Ridge, Tenn., Tensile and Impact Properties of Thick-Section Plate and Weldments, ORNLTM-3211, January 1971.

C. W. Hunter and J. A. Williams, Hanford Eng. Dev. Lab., Richland, Wash., Fracture and Tensile Behavior of Neutron-Irradiated A533-B Pressure Vessel Steel, HEDL-TME-71-76, Feb. 6, 1971. 
C. E. Childress, Union Carbide Corp. Nuclear Div., Oak Ridge Natl. Lab., Oak Ridge, Tenn., Manual for ASTM A533 Grade B Class 1 Steel (HSST Plate 03) Provided to the International Atomic Energy Agency, ORNL/TM-3193, March 1971.

P. N. Randall, TRW Systems Group, Redondo Beach, Calif., Gross Strain Crack Tolerance of A533-B Steel, HSSTP-TR-14, May 1, 1971.

C. L. Segaser, Union Carbide Corp. Nuclear Div., Oak Ridge Natl. Lab., Oak Ridge, Tenn., Feasibility Study, Irradiation of Heavy-Section Steel Specimens in the South Test Facility of the Oak Ridge Research Reactor, ORNL/TM-3234, May 1971.

H. T. Corten and R. H. Sailors, University of Illinois, Urbana, III., Relationship Between Material Fracture Toughness Using Fracture Mechanics and Transition Temperature Tests, T\&AM Report 346, Aug. 1, 1971.

L. A. James and J. A. Williams, Hanford Eng. Dev. Lab., Richland, Wash., Heavy Section Steel Technology Program Technical Report No. 21, The Effect of Temperature and Neutron Irradiation Upon the Fatigue-Crack Propagation Behavior of ASTM A533 Grade B, Class 1 Steel, HEDL-TME 72-132, September 1972.

P. B. Crosley and E. J. Ripling, Materials Research Laboratory, Inc., Glenwood, III., Crack Arrest in an Increasing K-Field, HSSTP-TR-27, January 1973.

W. J. Stelzman and R. G. Berggren, Union Carbide Corp. Nuclear Div., Oak Ridge Natl. Lab., Oak Ridge, Tenn., Radiation Strengthening and Embrittlement in Heavy-Section Steel Plates and Welds, ORNL-4871, June 1973.

J. M. Steichen and J. A. Williams, Hanford Eng. Dev. Lab., Richland, Wash., High Strain Rate Tensile Properties of Irradiated ASTM A533 Grade B Class 1 Pressure Vessel Steel, HEDL-TME 73-74, July 1973.

J. A. Williams, Hanford Eng. Dev. Lab., Richland, Wash., The Irradiation and Temperature Dependence of Tensile and Fracture Properties of ASTM A533, Grade B, Class 1 Steel Plate and Weldment, HEDL-TME 73-75, August 1973.

J. A. Williams, Hanford Eng. Dev. Lab., Richland, Wash., Some Comments Related to the Effect of Rate on the Fracture Toughness of Irradiated ASTM A553-B Steel Based on Yield Strength Behavior, HEDL-SA 797, December 1974.

J. A. Williams, Hanford Eng. Dev. Lab., Richland, Wash., The Irradiated Fracture Toughness of ASTM A533, Grade B, Class 1 Steel Measured with a Four-Inch-Thick Compact Tension Specimen, HEDL-TME 75-10, January 1975.

J. G. Merkle, G. D. Whitman, and R. H. Bryan, Union Carbide Corp. Nuclear Div., Oak Ridge Natl. Lab., Oak Ridge, Tenn., An Evaluation of the HSST Program Intermediate Pressure Vessel Tests in Terms of Light-Water-Reactor Pressure Vessel Safety, ORNL/TM-5090, November 1975.

J. A. Davidson, L. J. Ceschini, R. P. Shogan, and G. V. Rao, Westinghouse Electric Corporation, Pittsburgh, Pa., The Irradiated Dynamic Fracture Toughness of ASTM A533, Grade B, Class 1 Steel Plate and Submerged Arc Weldment, WCAP-8775, October 1976. 
J. A. Williams, Hanford Eng. Dev. Lab., Richland, Wash., Tensile Properties of Irradiated and Unirradiated Welds of A533 Steel Plate and A508 Forgings, NUREG/CR-1158

(ORNL/SUB-79/50917/2), July 1979.

J. A. Williams, Hanford Eng. Dev. Lab., Richland, Wash., The Ductile Fracture Toughness of HeavySection Steel Plate, NUREG/CR-0859, September 1979.

K. W. Carlson and J. A. Williams, Hanford Eng. Dev. Lab., Richland, Wash., The Effect of Crack Length and Side Grooves on the Ductile Fracture Toughness Properties of ASTM A533 Steel, NUREG/CR-1171 (ORNLSUB-79/50917/3), October 1979.

G. A. Clarke, Westinghouse Electric Corp., Pittsburgh, Pa., An Evaluation of the Unloading Compliance Procedure for J-Integral Testing in the Hot Cell, Final Report, NUREG/CR-1070 (ORNL/SUB-7394/1), October 1979.

P. B. Crosley and E. J. Ripling, Materials Research Laboratory, Inc., Glenwood, III., Development of a Standard Test for Measuring $K_{1 a}$ with a Modified Compact Specimen, NUREG/CR-2294

(ORNL/SUB-81/7755/1), August 1981.

H. A. Domian, Babcock and Wilcox Company, Alliance, Ohio, Vessel V-8 Repair and Preparation of Low Upper-Shelf Weldment, NUREG/CR-2676 (ORNL/SUB/81-85813/1), June 1982.

R. D. Cheverton, S. K. Iskander, and D. G. Ball, Union Carbide Corp. Nuclear Div., Oak Ridge Natl. Lab., Oak Ridge, Tenn., PWR Pressure Vessel Integrity During Overcooling Accidents: A Parametric Analysis, NUREG/CR-2895 (ORNLTM-7931), February 1983.

J. G. Merkle, Union Carbide Corp. Nuclear Div., Oak Ridge Natl. Lab., Oak Ridge, Tenn., An Examination of the Size Effects and Data Scatter Observed in Small Specimen Cleavage Fracture Toughness Testing, NUREG/CR-3672 (ORNL/TM-9088), April 1984.

W. R. Corwin, Martin Marietta Energy Systems, Inc., Oak Ridge Natl. Lab., Oak Ridge, Tenn., Assessment of Radiation Effects Relating to Reactor Pressure Vessel Cladding, NUREG/CR-3671 (ORNL-6047), July 1984.

W. R. Corwin, R. G. Berggren, and R. K. Nanstad, Martin Marietta Energy Systems, Inc., Oak Ridge Natl. Lab., Oak Ridge, Tenn., Charpy Toughness and Tensile Properties of a Neutron Irradiated Stäinless Steel Submerged-Arc Weld Cladding Overlay, NUREG/CR-3927 (ORNLTM-9709), September 1984.

J. J. McGowan, Martin Marietta Energy Systems, Inc., Oak Ridge Natl. Lab., Oak Ridge, Tenn., Tensile Properties of Irradiated Nuclear Grade Pressure Vessel Plate and Welds for the Fourth HSST Irradiation Series, NUREG/CR-3978 (ORNLTM-9516), January 1985.

J. J. McGowan, Martin Marietta Energy Systems, Inc., Oak Ridge Natl. Lab., Oak Ridge, Tenn., Tensile Properties of Irradiated Nuclear Grade Pressure Vessel Welds for the Third HSST Irradiation Series, NUREG/CR-4086 (ORNLTM-9477), March 1985.

W. R. Corwin, G. C. Robinson, R. K. Nanstad, J. G. Merkle, R. G. Berggren, G. M. Goodwin, R. L. Swain, and T. D. Owings, Martin Marietta Energy Systems, Inc., Oak Ridge Natl. Lab., Oak Ridge, Tenn., Effects of Stainless Steel Weld Overlay Cladding on the Structural Integrity of Flawed Steel Plates in Bending, Series 1, NUREG/CR-4015 (ORNL/TM-9390), April 1985. 
W. J. Stelzman, R. G. Berggren, and T. N. Jones, Martin Marietta Energy Systems, Inc., Oak Ridge Natl. Lab., Oak Ridge, Tenn., ORNL Characterization of Heavy-Section Steel Technology Program Plates 01, 02, and 03, NUREG/CR-4092 (ORNL/TM-9491), April 1985.

G. D. Whitman, Martin Marietta Energy Systems, Inc., Oak Ridge Natl. Lab., Oak Ridge, Tenn., Historical Summary of the Heavy-Section Steel Technology Program and Some Related Activities in Light-Water Reactor Pressure Vessel Safety Research, NUREG/CR-4489 (ORNL-6259), March 1986.

R. H. Bryan, B. R. Bass, S. E. Bolt, J. W. Bryson, J. G. Merkle, R. K. Nanstad, and G. C. Robinson, Martin Marietta Energy Systems, Inc., Oak Ridge Natl. Lab., Oak Ridge, Tenn., Test of 6-in.-Thick Pressure Vessels. Series 3: Intermediate Test Vessel V-8A - Tearing Behavior of Low Upper-Shelf Material, NUREG-CR-4760 (ORNL-6187), May 1987.

D. B. Barker, R. Chona, W. L. Fourney, and G. R. Irwin, University of Maryland, College Park, Md., A Report on the Round Robin Program Conducted to Evaluate the Proposed ASTM Standard Test Method for Determining the Plane Strain Crack Arrest Fracture Toughness, $K_{l a}$ of Ferritic Materials, NUREG/CR-4966 (ORNL/SUB/79-7778/4), January 1988.

L. F. Miller, C. A. Baldwin, F. W. Stallman, and F. B. K. Kam, Martin Marietta Energy Systems, Inc., Oak Ridge Natl. Lab., Oak Ridge, Tenn., Neutron Exposure Parameters for the Metallurgical Test Specimens in the Fifth Heavy-Section Steel Technology Irradiation Series Capsules, NUREG/CR-5019 (ORNL/TM-10582), March 1988.

J. J. McGowan, R. K. Nanstad, and K. R. Thoms, Martin Marietta Energy Systems, Inc., Oak Ridge Natl. Lab., Oak Ridge, Tenn., Characterization of Irradiated Current-Practice Welds and A533 Grade B Class 1 Plate for Nuclear Pressure Vessel Service, NUREG/CR-4880 (ORNL-6484N1 and V2), July 1988.

R. D. Cheverton, W. E. Pennell, G. C. Robinson, and R. K. Nanstad, Martin Marietta Energy Systems, Inc., Oak Ridge Natl. Lab., Oak Ridge, Tenn., Impact of Radiation Embrittlement on Integrity of Pressure Vessel Supports for Two PWR Plants, NUREG/CR-5320 (ORNL/TM-10966), February 1989.

J. G. Merkle, Martin Marietta Energy Systems, Inc., Oak Ridge Natl. Lab., Oak Ridge, Tenn., An Overview of the Low-Upper-Shelf Toughness Safety Margin Issue, NUREG/CR-5552 (ORNL/TM-11314), August 1990.

R. D. Cheverton, T. L. Dickson, J. G. Merkle, and R. K. Nanstad, Martin Marietta Energy Systems, Inc., Oak Ridge Natl. Lab., Oak Ridge, Tenn., Review of Reactor Pressure Vessel Evaluation Report for Yankee Rowe Nuclear Power Station (YAEC No. 1735), NUREG/CR-5799 (ORNL/TM-11982), March 1992. 


\title{
Neutron Exposure Parameters for the Dosimetry Capsule in the Heavy-Section Steel Irradiation Program Tenth Irradiation Series
}

\author{
I. Remec, C. A. Baldwin, and F. B. K. Kam
}

\section{Introduction}

\begin{abstract}
A variety of experiments and analyses for assessing the effects of neutron irradiation on metallurgical test specimens have been sponsored by the U.S. Nuclear Regulatory Commission (NRC). Results from these investigations should provide information that will lead to an improved understanding of the processes of neutron damage to pressure vessels and other structural materials. Thus, the lifetime of many nuclear reactors may be extended through knowledge gained from these experiments, and confidence in the accuracy of information relative to the integrity of reactor pressure vessels and of related components should be enhanced.
\end{abstract}

A new facility in which to perform the Heavy-Section Steel Irradiation (HSSI) Program irradiations was installed at the University of Michigan's Ford Nuclear Reactor in Ann Arbor, Michigan. Before any metallurgical capsule irradiation, an extensive dosimetry experiment was carried out to assess the neutron irradiation exposure rates and their distributions. The dosimetry experiment HSSI 10.0D included a simulated metallurgical capsule with special holes drilled through a steel block to allow precise positioning of the dosimeter tubes. A comprehensive set of dosimeters was irradiated inside the dosimeter tubes. In addition to the dosimeters inside the simulated capsule, removable dosimeter tube (RDT) dosimeters were irradiated just behind the thermal shield, outside the capsule. The RDT dosimeters can be removed on a cycle-to-cycle basis.

This report describes the computational methodology for the least-squares adjustment of the dosimetry data from the HSSI 10.0D dosimetry capsule with neutronics calculations. It presents exposure parameter rates at each dosimetry location for the neutron fluence rate greater than $1.0 \mathrm{MeV}$, fluence rate greater than $0.1 \mathrm{MeV}$, and displacement-per-atom (dpa) rate. Irradiation exposure rates determined should be useful for the estimation of irradiation times and exposure parameters of current and future HSSI irradiation experiments.

\section{Methodology of the Analysis}

To determine the neutron irradiation exposure parameters, a neutron spectrum adjustment procedure was used that combines transport calculations of the neutron field and measurements using radiometric monitors.

The input data required in this analysis consisted of the following:

- neutron fluence rate spectrum obtained from transport calculations at each dosimetry location,

- measured activity of each dosimeter,

- cross section for each dosimetry reaction used,

- location of each dosimetry set, and

- response function for each irradiation exposure parameter. 
Neutron transport calculations for the HSSI 10.0D capsule were performed by Williams.* The threedimensional fluence rate spectra for each dosimetry location were obtained by the flux synthesis method, which combines the results of two-dimensional and one-dimensional transport theory calculations. A 47-group neutron spectrum was provided at each of the dosimetry locations in the capsule and for the three fuel cycles.

A comprehensive set of radiometric monitors was irradiated in the dosimetry capsule. It consisted of ${ }^{59} \mathrm{Co}$ and ${ }^{109} \mathrm{Ag}$ thermal dosimeters and ${ }^{54} \mathrm{Fe}$ and ${ }^{63} \mathrm{Cu}$ threshold dosimeters, which were irradiated in the 27 locations inside the capsule. At five locations, ${ }^{58} \mathrm{Ni},{ }^{46} \mathrm{Ti},{ }^{237} \mathrm{~Np}$, and ${ }^{238} \mathrm{U}$ dosimeters were also used. At the five locations where fission dosimeters were used, the dosimeters were irradiated under 0.89-mm-thick (35-mil-thick) gadolinium covers; at the other locations, dosimeters were irradiated bare. The arrangement of the irradiation locations inside the capsule, labeled as P1 to P27, and the coordinate system are shown in Fig. 1. These labels and/or location coordinates are used throughout the tables in this report, where activities or irradiation exposure parameters are listed. The relative location of the irradiation capsule with respect to the reactor core is shown in Figs. 2 and 3 . The thickness of materials between the core and the dosimetry capsule are shown in Fig. 4 . The specific activities of neutron dosimeters at the end of irradiation are given in the Appendix.

The activation cross-section library and covariance information in 640 energy groups were created from the IRDF 90 and ENDF V dosimetry files. To account for the gadolinium cover, a modified set of cross sections was generated, where the 640-group cross sections were multiplied by attenuation factors defined as:

$$
A F=\exp [-(D \times A V I A T) \times T H \times C S]
$$

where
$A F=$ attenuation factor,
D = density of cover material $\left(7.9004 \mathrm{~g} / \mathrm{cm}^{3}\right.$ for $\left.\mathrm{Gd}\right)$,
$\mathrm{AV}=$ Avogadros number,
$\mathrm{AT}=$ atomic weight (157.25 for $\mathrm{Gd})$,
$\mathrm{TH}=$ thickness of the cover $(0.89 \mathrm{~mm}, 35 \mathrm{mil})$,
$\mathrm{CS}=$ total absorption cross section of $\mathrm{Gd}$ (taken from the IRDF 90 file).

This formula is, of course, a crude approximation only and does not consider the geometry of the covers and the dosimeters. However, it appears to be reasonably accurate for the current application. The resulting cross sections were then combined with the cross sections for bare dosimeters and were converted to 32 energy groups for use in the adjustment runs. Cross-section covariance matrixes were also converted to the 32-group structure. Computer code FLXPRO from the LSL-M2 code package was used for this purpose. ${ }^{1}$

\#M. L. Williams, Louisiana State University, Nuclear Science Center, personal communication to F. B. K. Kam. 


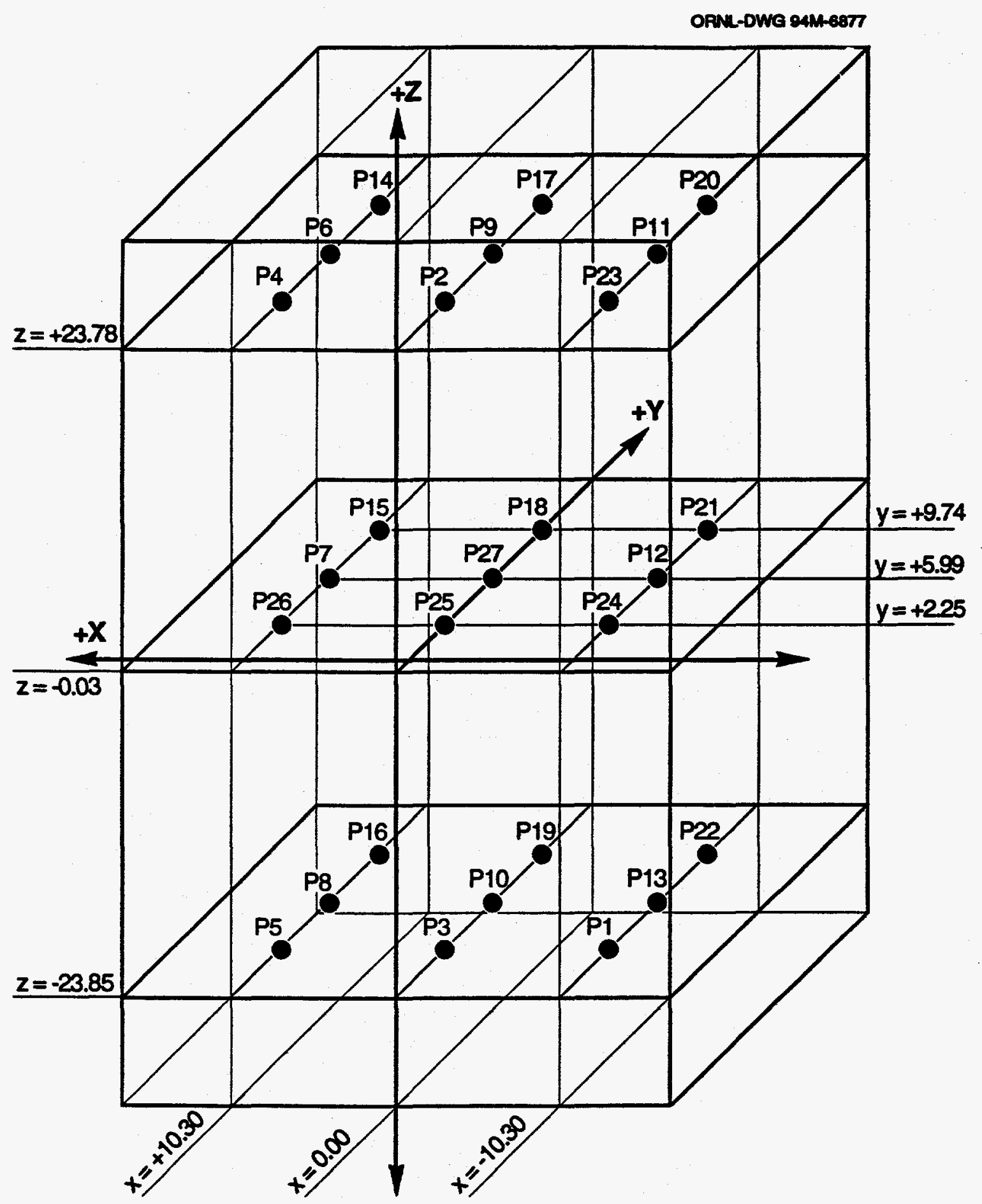

Figure 1. Arrangement of the dosimeter locations inside the HSSI 10.0D capsule.

Origin of the coordinate system is in the center of the front face of the capsule. 


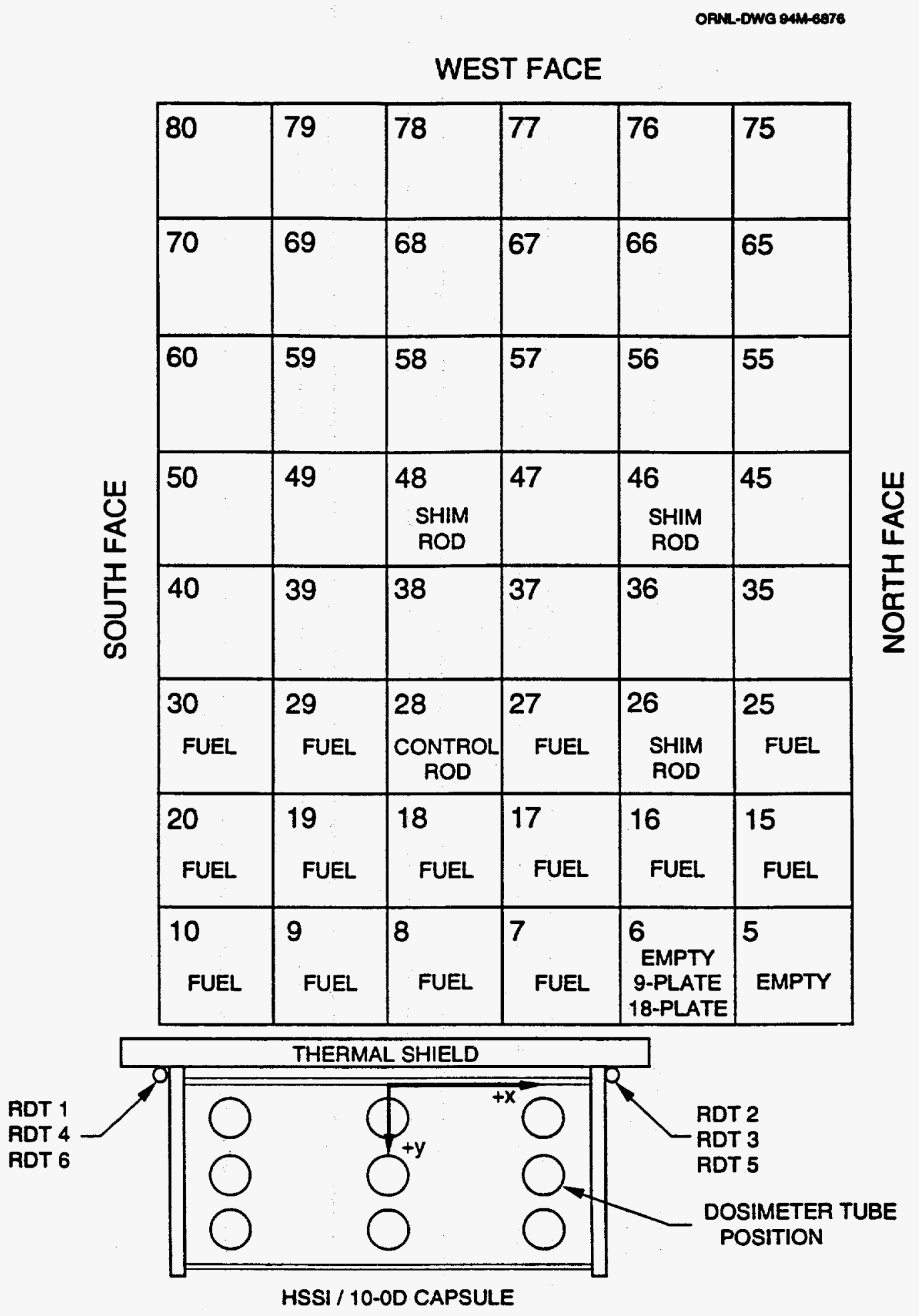

Figure 2. Location of the HSSI $10.0 \mathrm{D}$ capsule relative to the reactor core-horizontal cross section. 


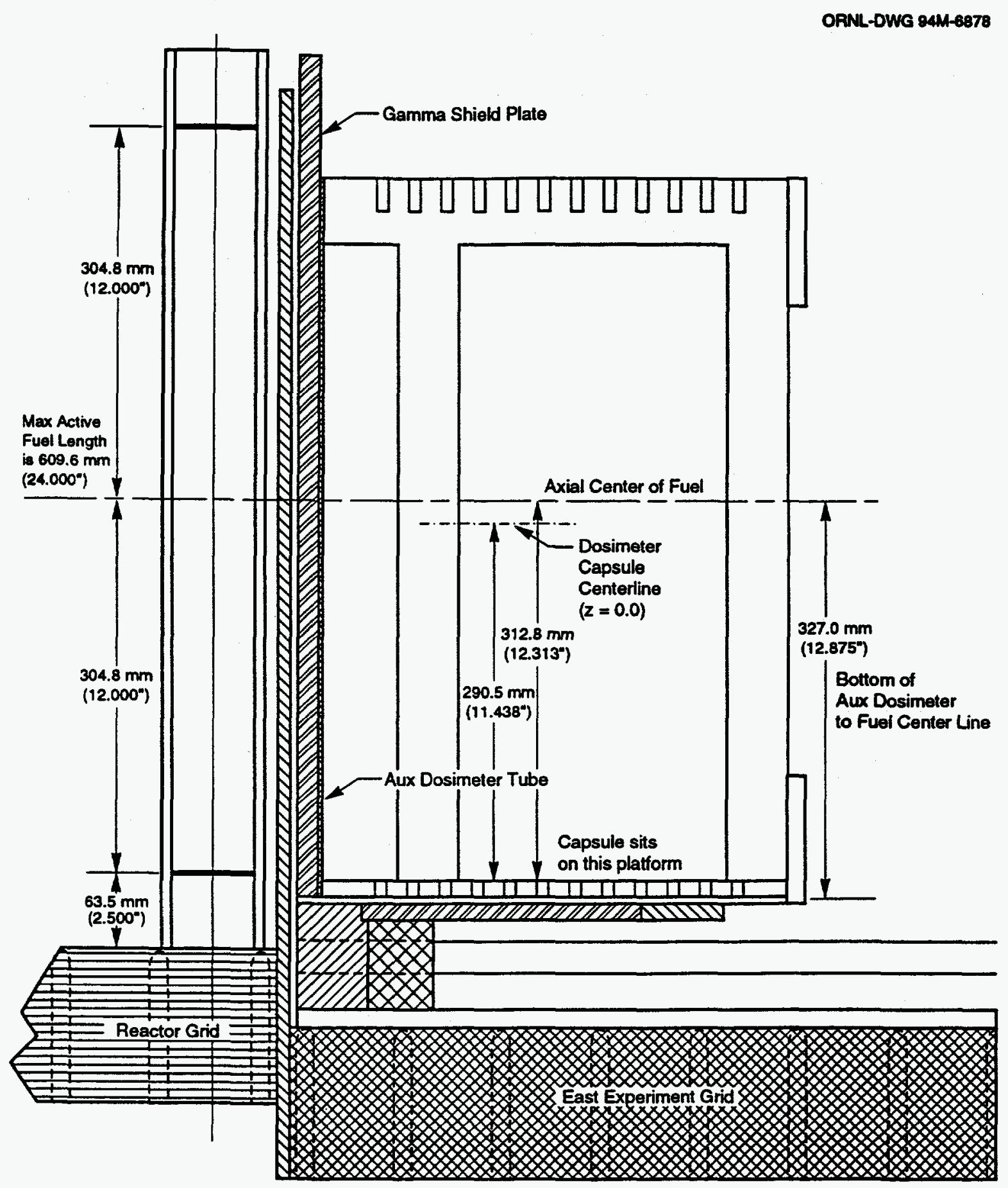

Figure 3. Location of the HSSI 10.0D capsule relative to the reactor core-vertical cross section. 


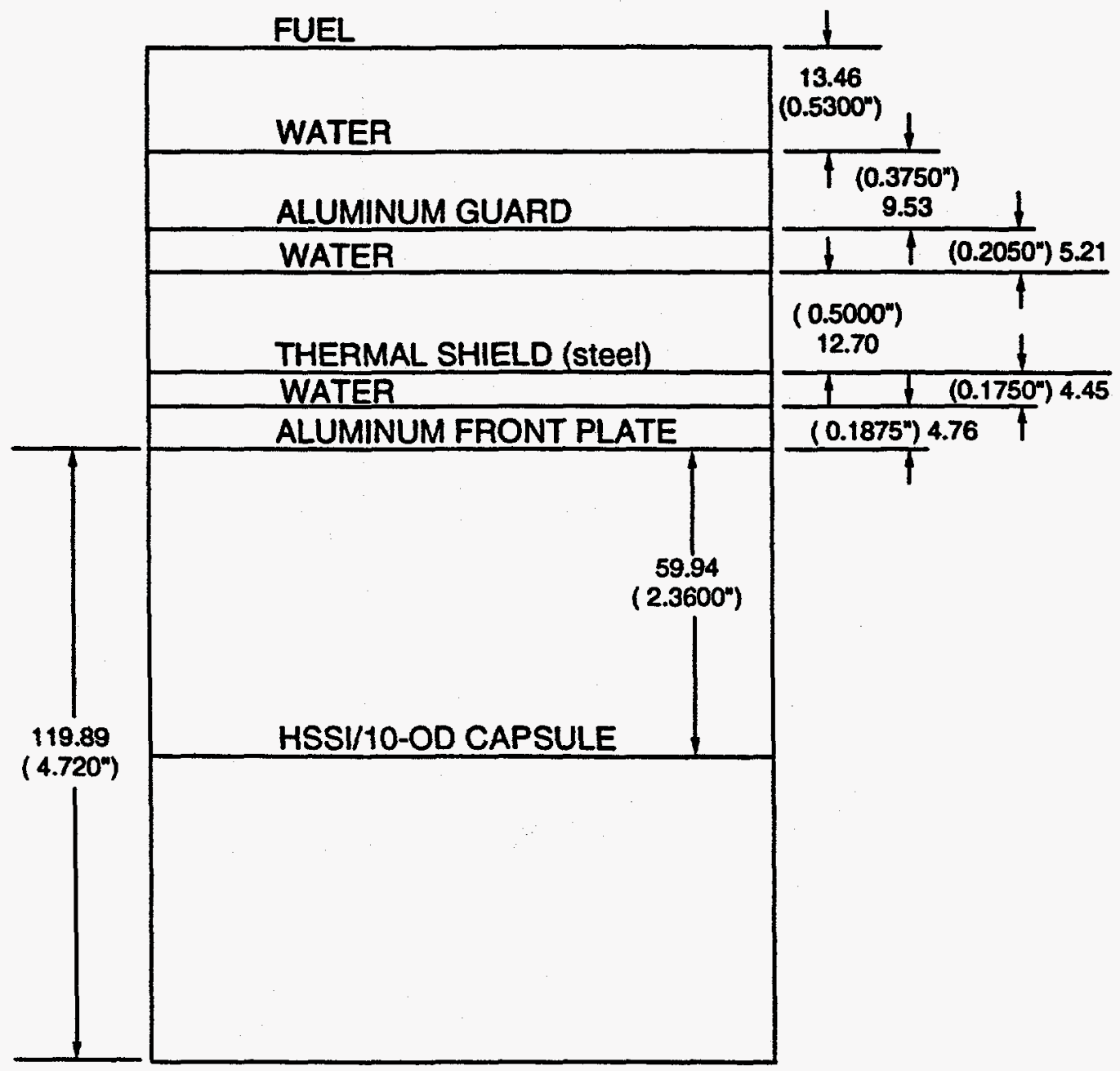

Figure 4. Thickness of materials between the core and the HSSI 10.0D dosimetry capsule. Dimensions are shown in millimeters and in inches within parentheses. 
Measured activities were converted to reaction probabilities, taking into account the reactor power history for the cycles of the irradiation. Computer code ACT from the LSL-M2 code package was used for this purpose. ${ }^{1}$ The reactor power history for the three cycles considered is shown in Table A.2 of the Appendix.

The spectrum covariance matrix was used, as calculated for the simulated surveillance capsule position for the Oak Ridge Research Reactor Poolside Facility Metallurgical Experiment. ${ }^{2,3}$ The original calculation of the fluence variance-covariances covered only the range from 18 to $0.1 \mathrm{MeV}$. Therefore, two energy groups from $1 \mathrm{E}-5$ to $0.1 \mathrm{eV}$ and from $0.1 \mathrm{eV}$ to $0.1 \mathrm{MeV}$ were added, with large variances of $150 \%$ and $75 \%$, respectively, and small correlations of 0.1 and 0.2 . The spectrum covariance matrix was converted in the group structure used in the adjustment with the computer code FLXPRO.

Obviously the assumed spectrum variance-covariance information is only approximate. However, it does not appear to be critical for the analysis since comprehensive dosimetry measurements are available, and in such cases the adjustment results are generally not sensitive to the details in the spectrum covariance matrix.

For the least-squares neutron spectrum adjustment calculations, computer code LSL-M2 was used. ${ }^{1}$ The adjustment runs provided the adjusted neutron spectrum at each location considered. The neutron irradiation exposure rates selected to characterize the irradiation conditions are neutron fluence rate with energy greater than $1 \mathrm{MeV}\left(\mathrm{F}_{E>1 \mathrm{MeV}}\right)$, neutron fluence rate with energy greater than $0.1 \mathrm{MeV}$ $\left(F_{E>0.1 \mathrm{MeV}}\right)$, and dpa rate. Fluence rates, $F_{E>1 \mathrm{Mev}}$ and $F_{E>0.1 \mathrm{MeV}}$, are obtained as sums of group fluxes over the corresponding energy range; however, for the dpa rate calculations, the cross sections used were taken from Ref. 4. These exposure parameters were determined for each dosimetry location and are listed in Tables 1 through 3. Listed exposure parameter rates are averages, representative of the three fuel cycles during which the HSSI 10.0D capsule was irradiated. Exposure parameters are given for reactor full-core power of $2 \mathrm{MW}$.

The exposure parameters obtained from the adjustment runs were fitted to an appropriate threedimensional function. It is desirable to describe the space variation of irradiation parameters by means of a three-dimensional function because the values of exposure parameters are often needed at locations other than the dosimetry locations. The function, used for fitting the irradiation parameters, was of the form

$$
F(x, y, z)=A \cos \left[B_{x}\left(x-x_{0}\right)\right] \cos \left[B_{z}\left(z-z_{0}\right)\right] \exp (-\lambda y)
$$

The constants $A, B_{x}, x_{0}, B_{z}, z_{0}$, and $\lambda$ were determined with least squares fitting and are listed in Table 4 for each of the three irradiation parameters. 
Table 1. Adjusted average fast fluence rates, $F_{E>1 \text { mev }}$, for cycles $338 \mathrm{~B}, 339 \mathrm{~B}$, and $340 \mathrm{~A}$ for all dosimetry locations

\begin{tabular}{|c|c|c|c|c|}
\hline \multirow[t]{2}{*}{ Location } & \multicolumn{3}{|c|}{ Coordinates } & \multirow{2}{*}{$\begin{array}{l}F_{E>1 M e V} \\
\left(\mathrm{~cm}^{-2} \mathrm{~s}^{-1}\right)\end{array}$} \\
\hline & $\begin{array}{c}X \\
(\mathrm{~cm})\end{array}$ & $\begin{array}{c}Y \\
(\mathrm{~cm})\end{array}$ & $\begin{array}{c}Z \\
(\mathrm{~cm})\end{array}$ & \\
\hline $\mathrm{P} 23$ & -10.30 & 2.25 & 23.78 & $5.017 \mathrm{E}+11$ \\
\hline P2 & 0.00 & 2.25 & 23.78 & $7.866 \mathrm{E}+11$ \\
\hline P4 & 10.30 & 2.25 & 23.78 & $7.862 E+11$ \\
\hline P11 & -10.30 & 5.99 & 23.78 & $2.689 E+11$ \\
\hline P9 & 0.00 & 5.99 & 23.78 & $4.250 \mathrm{E}+11$ \\
\hline P6 & 10.30 & 5.99 & 23.78 & $4.044 \mathrm{E}+11$ \\
\hline P20 & -10.30 & 9.74 & 23.78 & $1.392 E+11$ \\
\hline P17 & 0.00 & 9.74 & 23.78 & $2.195 E+11$ \\
\hline P14 & 10.30 & 9.74 & 23.78 & $2.060 E+11$ \\
\hline P24 & -10.30 & 2.25 & -0.03 & $7.975 E+11$ \\
\hline P25 & 0.00 & 2.25 & -0.03 & $1.295 E+12$ \\
\hline P26 & 10.30 & 2.25 & -0.03 & $1.320 \mathrm{E}+12$ \\
\hline $\mathrm{P} 12$ & -10.30 & 5.99 & -0.03 & $4.391 \mathrm{E}+11$ \\
\hline P27 & 0.00 & 5.99 & -0.03 & $7.084 E+11$ \\
\hline P7 & 10.30 & 5.99 & -0.03 & $6.780 \mathrm{E}+11$ \\
\hline P21 & -10.30 & 9.74 & -0.03 & $2.298 \mathrm{E}+11$ \\
\hline P18 & 0.00 & 9.74 & -0.03 & $3.678 E+11$ \\
\hline P15 & 10.30 & 9.74 & -0.03 & $3.453 E+11$ \\
\hline P1 & -10.30 & 2.25 & -23.85 & $3.710 \mathrm{E}+11$ \\
\hline P3 & 0.00 & 2.25 & -23.85 & $5.885 E+11$ \\
\hline P5 & 10.30 & 2.25 & -23.85 & $5.933 E+11$ \\
\hline P13 & -10.30 & 5.99 & -23.85 & $2.024 E+11$ \\
\hline P10 & 0.00 & 5.99 & -23.85 & $3.229 E+11$ \\
\hline P8 & 10.30 & 5.99 & -23.85 & $3.100 E+11$ \\
\hline P22 & -10.30 & 9.74 & -23.85 & $1.060 \mathrm{E}+11$ \\
\hline P19 & 0.00 & 9.74 & -23.85 & $1.689 E+11$ \\
\hline P16 & 10.30 & 9.74 & -23.85 & $1.587 \mathrm{E}+11$ \\
\hline
\end{tabular}


Table 2. Adjusted average fast fluence rates, $F_{E>0.1 ~ M e v}$, for cycles 338B, 339B, and 340A for all dosimetry locations

\begin{tabular}{|c|c|c|c|c|}
\hline \multirow[t]{2}{*}{ Location } & \multicolumn{3}{|c|}{ Coordinates } & \multirow{2}{*}{$\begin{array}{l}\mathrm{F}_{\mathrm{E}>0.1 \mathrm{MeV}} \\
\left(\mathrm{cm}^{-2} \mathrm{~s}^{-1}\right)\end{array}$} \\
\hline & $\begin{array}{c}X \\
(\mathrm{~cm})\end{array}$ & $\begin{array}{c}Y \\
(\mathrm{~cm}) \\
\end{array}$ & $\begin{array}{c}\mathrm{Z} \\
(\mathrm{cm})\end{array}$ & \\
\hline P23 & -10.30 & 2.25 & 23.78 & $1.254 \mathrm{E}+12$ \\
\hline P2 & 0.00 & 2.25 & 23.78 & 2.027E+12 \\
\hline P4 & 10.30 & 2.25 & 23.78 & $1.885 \mathrm{E}+12$ \\
\hline P11 & -10.30 & 5.99 & 23.78 & $8.018 \mathrm{E}+11$ \\
\hline P9 & 0.00 & 5.99 & 23.78 & $1.315 \mathrm{E}+12$ \\
\hline P6 & 10.30 & 5.99 & 23.78 & $1.124 E+12$ \\
\hline P20 & -10.30 & 9.74 & 23.78 & $4.734 \mathrm{E}+11$ \\
\hline P17 & 0.00 & 9.74 & 23.78 & $7.770 E+11$ \\
\hline P14 & 10.30 & 9.74 & 23.78 & $6.372 E+11$ \\
\hline P24 & -10.30 & 2.25 & -0.03 & $2.089 E+12$ \\
\hline P25 & 0.00 & 2.25 & -0.03 & $3.483 \mathrm{E}+12$ \\
\hline P26 & 10.30 & 2.25 & -0.03 & $3.297 E+12$ \\
\hline P12 & -10.30 & 5.99 & -0.03 & $1.378 \mathrm{E}+12$ \\
\hline P27 & 0.00 & 5.99 & -0.03 & $2.302 E+12$ \\
\hline P7 & 10.30 & 5.99 & -0.03 & $1.981 \mathrm{E}+12$ \\
\hline P21 & -10.30 & 9.74 & -0.03 & $8.248 E+11$ \\
\hline P18 & 0.00 & 9.74 & -0.03 & $1.371 E+12$ \\
\hline P15 & 10.30 & 9.74 & -0.03 & $1.126 \mathrm{E}+12$ \\
\hline P1 & -10.30 & 2.25 & -23.85 & $9.556 \mathrm{E}+11$ \\
\hline P3 & 0.00 & 2.25 & -23.85 & $1.559 \mathrm{E}+12$ \\
\hline P5 & 10.30 & 2.25 & -23.85 & $1.461 E+12$ \\
\hline P13 & -10.30 & 5.99 & -23.85 & $6.202 E+11$ \\
\hline P10 & 0.00 & 5.99 & -23.85 & $1.027 E+12$ \\
\hline P8 & 10.30 & 5.99 & -23.85 & $8.852 E+11$ \\
\hline P22 & -10.30 & 9.74 & -23.85 & $3.707 E+11$ \\
\hline P19 & 0.00 & 9.74 & -23.85 & $6.142 E+11$ \\
\hline P16 & 10.30 & 9.74 & -23.85 & $5.047 E+11$ \\
\hline
\end{tabular}


Table 3. Adjusted average displacement-per-atom (dpa) rates for cycles 338B, 339B, and 340A for all dosimetry locations

\begin{tabular}{|c|c|c|c|c|}
\hline \multirow[t]{2}{*}{ Location } & \multicolumn{3}{|c|}{ Coordinates } & \multirow{2}{*}{$\begin{array}{l}\text { dpa } \\
\left(s^{-1}\right)\end{array}$} \\
\hline & $\begin{array}{c}X \\
(\mathrm{~cm})\end{array}$ & $\begin{array}{c}Y \\
(\mathrm{~cm}) \\
\end{array}$ & $\begin{array}{c}Z \\
(\mathrm{~cm})\end{array}$ & \\
\hline P23 & -10.30 & 2.25 & 23.78 & $7.410 \mathrm{E}-10$ \\
\hline P2 & 0.00 & 2.25 & 23.78 & $1.174 \mathrm{E}-09$ \\
\hline P4 & 10.30 & 2.25 & 23.78 & 1.143E-09 \\
\hline P11 & -10.30 & 5.99 & 23.78 & 4.244E-10 \\
\hline P9 & 0.00 & 5.99 & 23.78 & $6.797 \mathrm{E}-10$ \\
\hline P6 & 10.30 & 5.99 & 23.78 & 6.163E-10 \\
\hline P20 & -10.30 & 9.74 & 23.78 & $2.340 \mathrm{E}-10$ \\
\hline P17 & 0.00 & 9.74 & 23.78 & $3.746 \mathrm{E}-10$ \\
\hline P14 & 10.30 & 9.74 & 23.78 & $3.304 E-10$ \\
\hline P24 & -10.30 & 2.25 & -0.03 & 1.187E-09 \\
\hline P25 & 0.00 & 2.25 & -0.03 & 1.936E-09 \\
\hline P26 & 10.30 & 2.25 & -0.03 & $1.921 \mathrm{E}-09$ \\
\hline P12 & -10.30 & 5.99 & -0.03 & $7.002 E-10$ \\
\hline P27 & 0.00 & 5.99 & -0.03 & 1.142E-09 \\
\hline P7 & 10.30 & 5.99 & -0.03 & 1.046E-09 \\
\hline P21 & -10.30 & 9.74 & -0.03 & 3.917E-10 \\
\hline P18 & 0.00 & 9.74 & -0.03 & $6.363 E-10$ \\
\hline P15 & 10.30 & 9.74 & -0.03 & $5.616 \mathrm{E}-10$ \\
\hline P1 & -10.30 & 2.25 & -23.85 & $5.499 E-10$ \\
\hline P3 & 0.00 & 2.25 & -23.85 & $8.791 E-10$ \\
\hline P5 & 10.30 & 2.25 & -23.85 & $8.622 E-10$ \\
\hline P13 & -10.30 & 5.99 & -23.85 & 3.201E-10 \\
\hline P10 & 0.00 & 5.99 & -23.85 & $5.182 \mathrm{E}-10$ \\
\hline P8 & 10.30 & 5.99 & -23.85 & 4.747E-10 \\
\hline P22 & -10.30 & 9.74 & -23.85 & $1.791 \mathrm{E}-10$ \\
\hline P19 & 0.00 & 9.74 & -23.85 & $2.898 \mathrm{E}-10$ \\
\hline P16 & 10.30 & 9.74 & -23.85 & 2.561E-10 \\
\hline
\end{tabular}


Table 4. Parameters from the three-dimensional fits of the exposure parameter rates*

\begin{tabular}{|c|c|c|c|c|c|c|}
\hline \multicolumn{7}{|c|}{ (A) Fitting parameters for $F_{E>1 \mathrm{MeV}}$} \\
\hline & $\begin{array}{c}A \\
\left(\mathrm{~cm}^{-2} \mathrm{~s}^{-1}\right)\end{array}$ & $\begin{array}{c}\mathrm{B}_{\mathrm{x}} \\
\left(\mathrm{cm}^{-1}\right)\end{array}$ & $\begin{array}{c}x_{0} \\
(\mathrm{~cm})\end{array}$ & $\begin{array}{c}\mathrm{B}_{\mathrm{z}} \\
\left(\mathrm{cm}^{-1}\right)\end{array}$ & $\begin{array}{c}z_{0} \\
(\mathrm{~cm})\end{array}$ & $\begin{array}{c}\lambda \\
\left(\mathrm{cm}^{-1}\right)\end{array}$ \\
\hline Average $^{\dagger}$ & $2.021 E+12$ & 0.06082 & 5.071 & 0.04252 & 2.030 & 0.1707 \\
\hline \multicolumn{7}{|c|}{ (B) Fitting parameters for $F_{E>0.1 \mathrm{Mev}}$} \\
\hline & $\begin{array}{c}\mathrm{A} \\
\left(\mathrm{cm}^{-2} \mathrm{~s}^{-1}\right)\end{array}$ & $\begin{array}{c}\mathrm{B}_{\mathrm{x}} \\
\left(\mathrm{cm}^{-1}\right)\end{array}$ & $\begin{array}{c}x_{0} \\
(\mathrm{~cm})\end{array}$ & $\begin{array}{c}\mathrm{B}_{\mathrm{z}} \\
\left(\mathrm{cm}^{-1}\right)\end{array}$ & $\begin{array}{c}z_{0} \\
(\mathrm{~cm})\end{array}$ & $\begin{array}{c}\lambda \\
\left(\mathrm{cm}^{-1}\right)\end{array}$ \\
\hline Average $^{\dagger}$ & $4.887 E+12$ & 0.06920 & 3.303 & 0.04337 & 1.706 & 0.1286 \\
\hline \multicolumn{7}{|c|}{ (C) Fitting parameters for dpa rate } \\
\hline & $\begin{array}{c}A \\
\left(s^{-1}\right)\end{array}$ & $\begin{array}{c}\mathrm{B}_{\mathrm{x}} \\
\left(\mathrm{cm}^{-1}\right)\end{array}$ & $\begin{array}{c}x_{0} \\
(\mathrm{~cm})\end{array}$ & $\begin{array}{c}\mathrm{B}_{\mathrm{z}} \\
\left(\mathrm{cm}^{-1}\right)\end{array}$ & $\begin{array}{c}z_{0} \\
(\mathrm{~cm})\end{array}$ & $\begin{array}{c}\lambda \\
\left(\mathrm{cm}^{-1}\right)\end{array}$ \\
\hline Average $^{+}$ & $2.890 \mathrm{E}-09$ & 0.06404 & 4.272 & 0.04262 & 1.998 & 0.1535 \\
\hline
\end{tabular}

*The fitting function is of the form

$F(x, y, z)=A \cos \left[B_{x}\left(x-x_{0}\right)\right] \cos \left[B_{z}\left(z-z_{0}\right)\right] \exp (-\lambda y)$,

and the coordinate system is as shown in Figs. 2 and 3 .

${ }^{\dagger}$ Average exposure parameter rates for cycles 338B, 339B, and 340A were used to calculate three-dimensional fitting parameters.

\section{Results}

Information presented herein consists of the following:

1. The fluence rates, $F_{E>1 \mathrm{MeV}}$ and $F_{E>0.1 \mathrm{MeV}}$, and the dpa rates for each dosimetry location are listed in Tables 1 through 3 . Values given were obtained from the least-squares adjustment procedure and are the averages of the exposure parameters for the cycles 338B, 339B, and 340A.

2. Constants derived for the fitting function (Eq. 2) for each exposure parameter are given in Table 4.

Exposure parameter rates at any location $(x, y$, or $z)$ can be readily calculated using Eq. 2 and the constants listed in Table 4. The coordinates of the point where exposure parameter rates are needed must be given in the coordinate system, as shown in Figs. 2 and 3 . Time-integrated exposure parameters can be obtained by multiplying the exposure rates by the time of irradiation expressed in effective full-power seconds.

Uncertainties are not accurately propagated through all the computational sequences, and there may be biases that are not recognized. However, uncertainties obtained from the least-squares adjustment procedure take into account estimated uncertainties of neutronics calculations and measured activities. Uncertainties of the exposure parameter rates obtained from the adjustment calculations are $\sim 5 \%$ $(1 \sigma)$. When irradiation exposure rates are calculated from Eq. 2, uncertainty arising from the threedimensional fitting should be also considered. Differences between the exposure parameter rates at 
the dosimetry locations as obtained from the adjustment and as calculated from the fitting function are on the order of 3\% (average), as illustrated in Tables A.5 through A.7 in the Appendix. Therefore, for the irradiation exposure rates obtained from Eq. 2, an uncertainty of $6 \%(1 \sigma)$ is considered to be a good estimate.

\section{Conclusion}

The irradiation exposure parameter rate distributions in the HSSI 10.0D dosimetry capsule were determined. Exposure rate distributions are described in terms of values at dosimetry locations and in terms of three-dimensional fitting functions. When fitting functions are used, it is suggested that an uncertainty of $6 \%(1 \sigma)$ be associated with the exposure rate values. Irradiation exposure rates determined should be useful for the estimation of irradiation times and exposure parameters of current and future HSSI metallurgical irradiation experiments.

\section{References}

1. F. W. Stallmann, Lockheed Martin Energy Research Corporation, Oak Ridge Natl. Lab., Oak Ridge, Tenn., LSL-M2: A Computer Program for Least-Squares Logarithmic Adjustment of Neutron Spectra, USNRC Report NUREG/CR-4349 (ORNL/TM-9933), March 1986.

2. R. E. Maerker et al., Electric Power Research Institute, Palo Alto, Calif., Revision and Extension of the Data Base in the LEPRICON Dosimetry Methodology, EPRI NP-3841, January 1985.

3. F. W. Stalimann, Lockheed Martin Energy Research Corporation, Oak Ridge Natl. Lab., Oak Ridge, Tenn., Determination of the Damage Exposure Parameter Values in the PSF Metallurgical Irradiation Experiment, USNRC Report NUREG/CR-3841 (ORNL/TM-9166), October 1984.

4. American Society for Testing and Materials (ASTM), E-693, Standard Practice for Characterizing Neutron Exposures in Ferritic Steels in Terms of Displacements Per Atom (DPA), Annual Book of ASTM Standards. 


\section{Appendix}

The data included in this Appendix should be sufficient for another organization to recalculate the exposure parameters if fluence rate spectra are available or if neutronics calculations are performed. In particular, the data included herein are (1) specific activities of each dosimeter at the end of irradiation (EOI), (2) coordinates of each dosimeter relative to the coordinate system shown in Figs. 2 and 3 , and (3) the irradiation history of the capsule. In addition, cycle-to-cycle variations caused by changes in the core configuration are discussed through a comparison of the specific activities of the removable dosimeter tube (RDT) dosimeters. Finally, the suitability of the three-dimensional fitting function for determination of the irradiation parameters is accessed.

The specific activity of each dosimeter at the end of irradiation is listed in Table A.1. The in-capsule dosimetry was irradiated for three fuel cycles. The irradiation history is given in Table A.2. Additional dosimetry in the form of Co/Al and Fe wires was located in RDTs just behind the thermal shield (Fig. 2). RDT dosimeters were changed after each fuel cycle to allow the assessment of cycle-to-cycle variations in fluence rate magnitude and spatial distribution. Because the lengths of fuel cycles did not vary significantly, a comparison of the measured specific activities can be used directly to monitor relative cycle-to-cycle changes in fluence rate. The ${ }^{54} \mathrm{Mn}$ and ${ }^{60} \mathrm{Co}$ activities provide information about the fast and thermal fluence rates, respectively. Measured specific activities of the RDT dosimeters are listed in Table A.3. Table A.4 gives a comparison of the activities for the three cycles analyzed; values given are relative to the activities measured for cycle 338B. Maximum cycle-to-cycle variations in the ${ }^{54} \mathrm{Mn}$ specific activities are on the order of $10 \%$ and $30 \%$ for the RDT at the south and north sides of the capsule, respectively. Higher variations in the RDT dosimeter activities at the north side were caused by using three different types of fuel elements in core position 6 (see Fig 2). For cycle 338B, an unfueled plug was put in position 6. For cycle 339B, a 9-plate element occasionally used for adjusting core reactivity was used. Finally, for cycle $340 \mathrm{~B}$, a normal 18-plate element was used in position 6. Using different types of fuel elements in core position 6 also affected the side-to-side gradient (in the direction of $X$ axis) of the neutron field across the capsule. For the three cycles analyzed, the specific ${ }^{54} \mathrm{Mn}$ activities from the RDT on the north side of the capsule were approximately 2.0, 2.3, and 2.7 times higher, respectively, than the activities from the RDT on the south side of the capsule. However, most of the north-to-south decrease in the neutron field is because of the capsule location near the southeast core corner. The side-to-side ( $X$ axis direction) and axial ( $Z$ axis direction) variations in the specific activities of the RDT dosimeters are illustrated in Figs. A.1 through A.3. In the axial direction the ratio of maximum to minimum specific activity of ${ }^{54} \mathrm{Mn}$ is around 1.7 at both sides of the capsule and does not vary with the cycles. Figures A.4 through A.6 show that the shapes of the axial distributions of specific activities are almost the same on both sides of the capsule even though the magnitudes are different.

Tables A.5 through A.7 show the suitability of the three-dimensional fitting function for the irradiation parameters determination. The irradiation parameters $F_{E>1 \mathrm{MeV}}, F_{E>0.1 \mathrm{MeV}}$, and dpa rate at the dosimetry locations obtained from the adjustment procedure are compared with the values calculated using Eq. 2 and the fitting parameters from Table 4. It can be seen that the agreement between the adjusted and fitted values is good, with the average difference ranging from 2 to $3 \%$. 
Table A.1. Activities of the dosimeters in the HSSI 10.0D dosimetry capsule

\begin{tabular}{|c|c|c|c|c|c|}
\hline \multirow{2}{*}{$\begin{array}{c}\text { Monitor } \\
\text { ID }\end{array}$} & \multirow[t]{2}{*}{ Reaction } & \multicolumn{3}{|c|}{ Coordinates } & \multirow{2}{*}{$\begin{array}{l}\text { Activity* } \\
\text { at EOI } \\
(\mathrm{Bq} / \mathrm{mg})\end{array}$} \\
\hline & & $\begin{array}{c}X \\
(\mathrm{~cm})\end{array}$ & $\begin{array}{c}Y \\
(\mathrm{~cm})\end{array}$ & $\underset{(\mathrm{cm})}{Z}$ & \\
\hline $\begin{array}{l}\text { GS01-Co } \\
\text { GS01-Ag } \\
\text { GS01-Fe } \\
\text { GS01-Cu }\end{array}$ & $\begin{array}{l}\text { Co-59 }(n, g) \text { Co-60 } \\
\text { Ag-109 }(n, g) \text { Ag-110m } \\
\text { Fe-54 (n,p) Mn-54 } \\
\text { Cu-63 }(n, a) \text { Co-60 }\end{array}$ & $\begin{array}{l}-10.300 \\
-10.300 \\
-10.300 \\
-10.300\end{array}$ & $\begin{array}{l}2.250 \\
2.250 \\
2.250 \\
2.250\end{array}$ & $\begin{array}{l}-23.850 \\
-23.850 \\
-23.850 \\
-23.850\end{array}$ & $\begin{array}{l}7.98 E+02 \\
1.26 E+03 \\
1.02 E+03 \\
1.21 E+01\end{array}$ \\
\hline $\begin{array}{l}\text { GSO2-Co } \\
\text { GSO2-Ag } \\
\text { GSO2-Fe } \\
\text { GSO2-Cu }\end{array}$ & $\begin{array}{l}\text { Co-59 }(n, g) \text { Co-60 } \\
\text { Ag-109 }(n, g) \text { Ag-110m } \\
\text { Fe-54 (n,p) Mn-54 } \\
\text { Cu-63 }(n, a) \text { Co-60 }\end{array}$ & $\begin{array}{l}0.000 \\
0.000 \\
0.000 \\
0.000\end{array}$ & $\begin{array}{l}2.250 \\
2.250 \\
2.250 \\
2.250\end{array}$ & $\begin{array}{l}23.780 \\
23.780 \\
23.780 \\
23.780\end{array}$ & $\begin{array}{l}1.63 E+03 \\
3.09 E+03 \\
2.18 E+03 \\
2.55 E+01\end{array}$ \\
\hline $\begin{array}{l}\text { GSO3-Co } \\
\text { GSO3-Ag } \\
\text { GSO3-Fe } \\
\text { GSO3-Cu }\end{array}$ & $\begin{array}{l}\mathrm{Co}-59(n, g) \text { Co-60 } \\
\text { Ag-109 (n,g) Ag-110m } \\
\text { Fe-54 (n,p) Mn-54 } \\
\text { Cu-63 (n,a) Co-60 }\end{array}$ & $\begin{array}{l}0.000 \\
0.000 \\
0.000 \\
0.000\end{array}$ & $\begin{array}{l}2.250 \\
2.250 \\
2.250 \\
2.250\end{array}$ & $\begin{array}{l}-23.850 \\
-23.850 \\
-23.850 \\
-23.850\end{array}$ & $\begin{array}{l}1.07 E+03 \\
1.99 E+03 \\
1.50 E+03 \\
1.81 E+01\end{array}$ \\
\hline $\begin{array}{l}\text { GSO4-Co } \\
\text { GSO4-Ag } \\
\text { GSO4-Fe } \\
\text { GSO4-Cu }\end{array}$ & $\begin{array}{l}\mathrm{Co}-59(n, g) \mathrm{Co}-60 \\
\mathrm{Ag}-109(n, g) \mathrm{Ag}-110 \mathrm{~m} \\
\mathrm{Fe}-54(n, p) \mathrm{Mn}-54 \\
\mathrm{Cu}-63(n, a) \mathrm{Co}-60\end{array}$ & $\begin{array}{l}10.300 \\
10.300 \\
10.300 \\
10.300\end{array}$ & $\begin{array}{l}2.250 \\
2.250 \\
2.250 \\
2.250\end{array}$ & $\begin{array}{l}23.780 \\
23.780 \\
23.780 \\
23.780\end{array}$ & $\begin{array}{l}1.83 E+03 \\
3.09 E+03 \\
2.24 E+03 \\
2.69 E+01\end{array}$ \\
\hline $\begin{array}{l}\text { GSO5-Co } \\
\text { GSO5-Ag } \\
\text { GS05-Fe } \\
\text { GS05-Cu }\end{array}$ & $\begin{array}{l}\mathrm{Co}-59(n, g) \text { Co-60 } \\
\mathrm{Ag}-109(n, g) \mathrm{Ag}-110 \mathrm{~m} \\
\mathrm{Fe}-54(n, p) \mathrm{Mn}-54 \\
\mathrm{Cu}-63(n, a) \mathrm{Co}-60\end{array}$ & $\begin{array}{l}10.300 \\
10.300 \\
10.300 \\
10.300\end{array}$ & $\begin{array}{l}2.250 \\
2.250 \\
2.250 \\
2.250\end{array}$ & $\begin{array}{l}-23.850 \\
-23.850 \\
-23.850 \\
-23.850\end{array}$ & $\begin{array}{l}1.25 E+03 \\
1.98 E+03 \\
1.60 E+03 \\
1.92 E+01\end{array}$ \\
\hline $\begin{array}{l}\text { GS06-Co } \\
\text { GS06-Ag } \\
\text { GSO6-Fe } \\
\text { GS06-Cu }\end{array}$ & $\begin{array}{l}\mathrm{Co}-59(n, g) \mathrm{Co}-60 \\
\mathrm{Ag}-109(n, g) \mathrm{Ag}-110 \mathrm{~m} \\
\mathrm{Fe}-54(n, p) \mathrm{Mn}-54 \\
\mathrm{Cu}-63(n, a) \mathrm{Co}-60\end{array}$ & $\begin{array}{l}10.300 \\
10.300 \\
10.300 \\
10.300\end{array}$ & $\begin{array}{l}5.990 \\
5.990 \\
5.990 \\
5.990\end{array}$ & $\begin{array}{l}23.780 \\
23.780 \\
23.780 \\
23.780\end{array}$ & $\begin{array}{l}6.05 E+02 \\
1.28 E+03 \\
1.02 E+03 \\
1.13 E+01\end{array}$ \\
\hline $\begin{array}{l}\text { GSO7-Co } \\
\text { GS07-Ag } \\
\text { GS07-Fe } \\
\text { GS07-Cu }\end{array}$ & $\begin{array}{l}\mathrm{Co}-59(n, g) \mathrm{Co}-60 \\
\mathrm{Ag}-109(n, g) \mathrm{Ag}-110 \mathrm{~m} \\
\mathrm{Fe}-54(n, p) \mathrm{Mn}-54 \\
\mathrm{Cu}-63(n, a) \mathrm{Co}-60\end{array}$ & $\begin{array}{l}10.300 \\
10.300 \\
10.300 \\
10.300\end{array}$ & $\begin{array}{l}5.990 \\
5.990 \\
5.990 \\
5.990\end{array}$ & $\begin{array}{l}-0.030 \\
-0.030 \\
-0.030 \\
-0.030\end{array}$ & $\begin{array}{l}1.14 \mathrm{E}+03 \\
2.22 \mathrm{E}+03 \\
1.51 \mathrm{E}+03 \\
1.76 \mathrm{E}+01\end{array}$ \\
\hline $\begin{array}{l}\text { GSO8-Co } \\
\text { GSO8-Ag } \\
\text { GS08-Fe } \\
\text { GS08-Cu }\end{array}$ & $\begin{array}{l}\mathrm{Co}-59(n, g) \mathrm{Co}-60 \\
\mathrm{Ag}-109(n, g) \mathrm{Ag}-110 \mathrm{~m} \\
\mathrm{Fe}-54(n, p) \mathrm{Mn}-54 \\
\mathrm{Cu}-63(n, a) \mathrm{Co}-60\end{array}$ & $\begin{array}{l}10.300 \\
10.300 \\
10.300 \\
10.300\end{array}$ & $\begin{array}{l}5.990 \\
5.990 \\
5.990 \\
5.990\end{array}$ & $\begin{array}{l}-23.850 \\
-23.850 \\
-23.850 \\
-23.850\end{array}$ & $\begin{array}{l}5.50 \mathrm{E}+02 \\
9.66 \mathrm{E}+02 \\
7.21 \mathrm{E}+02 \\
8.57 \mathrm{E}+00\end{array}$ \\
\hline $\begin{array}{l}\text { GSO9-Co } \\
\text { GS09-Ag } \\
\text { GSO9-Fe } \\
\text { GSO9-Cu }\end{array}$ & $\begin{array}{l}\mathrm{Co-59}(\mathrm{n}, \mathrm{g}) \mathrm{Co}-60 \\
\mathrm{Ag}-109(\mathrm{n}, \mathrm{g}) \mathrm{Ag}-110 \mathrm{~m} \\
\mathrm{Fe}-54(\mathrm{n}, \mathrm{p}) \mathrm{Mn}-54 \\
\mathrm{Cu}-63(\mathrm{n}, \mathrm{a}) \mathrm{Co}-60\end{array}$ & $\begin{array}{l}0.000 \\
0.000 \\
0.000 \\
0.000\end{array}$ & $\begin{array}{l}5.990 \\
5.990 \\
5.990 \\
5.990\end{array}$ & $\begin{array}{l}23.780 \\
23.780 \\
23.780 \\
23.780\end{array}$ & $\begin{array}{l}6.62 E+02 \\
1.41 E+03 \\
9.73 E+02 \\
1.36 E+01\end{array}$ \\
\hline $\begin{array}{l}\text { GS10-Co } \\
\text { GS10-Ag } \\
\text { GS10-Fe } \\
\text { GS10-Cu }\end{array}$ & $\begin{array}{l}\text { Co-59 (n,g) Co-60 } \\
\text { Ag-109 (n,g) Ag-110m } \\
\text { Fe-54 (n,p) Mn-54 } \\
\text { Cu-63 (n,a) Co-60 }\end{array}$ & $\begin{array}{l}0.000 \\
0.000 \\
0.000 \\
0.000\end{array}$ & $\begin{array}{l}5.990 \\
5.990 \\
5.990 \\
5.990\end{array}$ & $\begin{array}{l}-23.850 \\
-23.850 \\
-23.850 \\
-23.850\end{array}$ & $\begin{array}{l}4.29 E+02 \\
9.48 E+02 \\
6.95 E+02 \\
8.01 E+00\end{array}$ \\
\hline
\end{tabular}


Table A.1 (continued)

\begin{tabular}{|c|c|c|c|c|c|}
\hline \multirow{2}{*}{$\begin{array}{c}\text { Monitor } \\
\text { ID }\end{array}$} & \multirow[t]{2}{*}{ Reaction } & \multicolumn{3}{|c|}{ Coordinates } & \multirow{2}{*}{$\begin{array}{l}\text { Activity* } \\
\text { at EOI } \\
(\mathrm{Bq} / \mathrm{mg})\end{array}$} \\
\hline & & $\underset{(\mathrm{cm})}{X}$ & $\begin{array}{c}Y \\
(\mathrm{~cm})\end{array}$ & $\underset{(\mathrm{cm})}{Z}$ & \\
\hline $\begin{array}{l}\text { GS11-Co } \\
\text { GS11-Ag } \\
\text { GS11-Fe } \\
\text { GS11-Cu }\end{array}$ & $\begin{array}{l}\text { Co-59 }(n, g) \text { Co-60 } \\
\text { Ag-109 (n,g) Ag-110m } \\
\text { Fe-54 (n,p) Mn-54 } \\
\text { Cu-63 (n,a) Co-60 }\end{array}$ & $\begin{array}{l}-10.300 \\
-10.300 \\
-10.300 \\
-10.300\end{array}$ & $\begin{array}{l}5.990 \\
5.990 \\
5.990 \\
5.990\end{array}$ & $\begin{array}{l}23.780 \\
23.780 \\
23.780 \\
23.780\end{array}$ & $\begin{array}{l}5.33 E+02 \\
9.84 E+02 \\
6.51 E+02 \\
8.01 E+00\end{array}$ \\
\hline $\begin{array}{l}\text { GS12-Co } \\
\text { GS12-Ag } \\
\text { GS12-Fe } \\
\text { GS12-Cu }\end{array}$ & $\begin{array}{l}\text { Co-59 (n,g) Co-60 } \\
\text { Ag-109 (n,g) Ag-110m } \\
\text { Fe-54 (n,p) Mn-54 } \\
\text { Cu-63 (n,a) Co-60 }\end{array}$ & $\begin{array}{l}-10.300 \\
-10.300 \\
-10.300 \\
-10.300\end{array}$ & $\begin{array}{l}5.990 \\
5.990 \\
5.990 \\
5.990\end{array}$ & $\begin{array}{l}-0.030 \\
-0.030 \\
-0.030 \\
-0.030\end{array}$ & $\begin{array}{l}7.37 E+02 \\
1.44 E+03 \\
9.63 E+02 \\
1.11 E+01\end{array}$ \\
\hline $\begin{array}{l}\text { GS13-Co } \\
\text { GS13-Ag } \\
\text { GS13-Fe } \\
\text { GS13-Cu }\end{array}$ & $\begin{array}{l}\mathrm{Co}-59(n, g) \mathrm{Co}-60 \\
\mathrm{Ag}-109(n, g) \mathrm{Ag}-110 \mathrm{~m} \\
\mathrm{Fe}-54(n, p) \mathrm{Mn}-54 \\
\mathrm{Cu}-63(n, a) \mathrm{Co}-60\end{array}$ & $\begin{array}{l}-10.300 \\
-10.300 \\
-10.300 \\
-10.300\end{array}$ & $\begin{array}{l}5.990 \\
5.990 \\
5.990 \\
5.990\end{array}$ & $\begin{array}{l}-23.850 \\
-23.850 \\
-23.850 \\
-23.850\end{array}$ & $\begin{array}{l}3.63 E+02 \\
6.32 E+02 \\
4.65 E+02 \\
5.56 E+00\end{array}$ \\
\hline $\begin{array}{l}\text { GS14-Co } \\
\text { GS14-Ag } \\
\text { GS14-Fe } \\
\text { GS14-Cu }\end{array}$ & $\begin{array}{l}\mathrm{Co}-59(n, g) \mathrm{Co}-60 \\
\mathrm{Ag}-109(n, g) \mathrm{Ag}-110 \mathrm{~m} \\
\mathrm{Fe}-54(n, p) \mathrm{Mn}-54 \\
\mathrm{Cu}-63(n, a) \mathrm{Co}-60\end{array}$ & $\begin{array}{l}10.300 \\
10.300 \\
10.300 \\
10.300\end{array}$ & $\begin{array}{l}9.740 \\
9.740 \\
9.740 \\
9.740\end{array}$ & $\begin{array}{l}23.780 \\
23.780 \\
23.780 \\
23.780\end{array}$ & $\begin{array}{l}5.81 E+02 \\
8.11 E+02 \\
4.72 E+02 \\
5.56 E+00\end{array}$ \\
\hline $\begin{array}{l}\text { GS15-Co } \\
\text { GS15-Ag } \\
\text { GS15-Fe } \\
\text { GS15-Cu }\end{array}$ & $\begin{array}{l}\mathrm{Co}-59(n, g) \mathrm{Co}-60 \\
\mathrm{Ag}-109(n, g) \mathrm{Ag}-110 \mathrm{~m} \\
\mathrm{Fe}-54(n, p) \mathrm{Mn}-54 \\
\mathrm{Cu}-63(n, a) \mathrm{Co}-60\end{array}$ & $\begin{array}{l}10.300 \\
10.300 \\
10.300 \\
10.300\end{array}$ & $\begin{array}{l}9.740 \\
9.740 \\
9.740 \\
9.740\end{array}$ & $\begin{array}{l}-0.030 \\
-0.030 \\
-0.030 \\
-0.030\end{array}$ & $\begin{array}{l}0.00 \mathrm{E}+00^{\star \star} \\
1.27 \mathrm{E}+03 \\
7.13 \mathrm{E}+02 \\
8.33 \mathrm{E}+00\end{array}$ \\
\hline $\begin{array}{l}\text { GS16-Co } \\
\text { GS16-Ag } \\
\text { GS16-Fe } \\
\text { GS16-Cu }\end{array}$ & $\begin{array}{l}\text { Co-59 }(n, g) \text { Co-60 } \\
\text { Ag-109 (n,g) Ag-110m } \\
\text { Fe-54 (n,p) Mn-54 } \\
\text { Cu-63 (n,a) Co-60 }\end{array}$ & $\begin{array}{l}10.300 \\
10.300 \\
10.300 \\
10.300\end{array}$ & $\begin{array}{l}9.740 \\
9.740 \\
9.740 \\
9.740\end{array}$ & $\begin{array}{l}-23.850 \\
-23.850 \\
-23.850 \\
-23.850\end{array}$ & $\begin{array}{l}4.34 \mathrm{E}+02 \\
5.96 \mathrm{E}+02 \\
3.48 \mathrm{E}+02 \\
4.11 \mathrm{E}+00\end{array}$ \\
\hline $\begin{array}{l}\text { GS17-Co } \\
\text { GS17-Ag } \\
\text { GS17-Fe } \\
\text { GS17-Cu }\end{array}$ & $\begin{array}{l}\mathrm{Co-59}(\mathrm{n}, \mathrm{g}) \mathrm{Co-60} \\
\mathrm{Ag}-109(\mathrm{n}, \mathrm{g}) \mathrm{Ag}-110 \mathrm{~m} \\
\mathrm{Fe}-54(\mathrm{n}, \mathrm{p}) \mathrm{Mn}-54 \\
\mathrm{Cu}-63(\mathrm{n}, \mathrm{a}) \mathrm{Co}-60\end{array}$ & $\begin{array}{l}0.000 \\
0.000 \\
0.000 \\
0.000\end{array}$ & $\begin{array}{l}9.740 \\
9.740 \\
9.740 \\
9.740\end{array}$ & $\begin{array}{l}23.780 \\
23.780 \\
23.780 \\
23.780\end{array}$ & $\begin{array}{l}4.71 E+02 \\
8.32 E+02 \\
4.44 E+02 \\
5.13 E+00\end{array}$ \\
\hline $\begin{array}{l}\text { GS18-Co } \\
\text { GS18-Ag } \\
\text { GS18-Fe } \\
\text { GS18-Cu }\end{array}$ & $\begin{array}{l}\text { Co-59 }(n, g) \text { Co-60 } \\
\text { Ag-109 (n,g) Ag-110m } \\
\text { Fe-54 (n,p) Mn-54 } \\
\text { Cu-63 (n,a) Co-60 }\end{array}$ & $\begin{array}{l}0.000 \\
0.000 \\
0.000 \\
0.000\end{array}$ & $\begin{array}{l}9.740 \\
9.740 \\
9.740 \\
9.740\end{array}$ & $\begin{array}{l}-0.030 \\
-0.030 \\
-0.030 \\
-0.030\end{array}$ & $\begin{array}{l}6.90 E+02 \\
1.19 E+03 \\
6.71 E+02 \\
7.57 E+00\end{array}$ \\
\hline $\begin{array}{l}\text { GS19-Co } \\
\text { GS19-Ag } \\
\text { GS19-Fe } \\
\text { GS19-Cu }\end{array}$ & $\begin{array}{l}\text { Co-59 (n,g) Co-60 } \\
\text { Ag-109 (n,g) Ag-110m } \\
\text { Fe-54 (n,p) Mn-54 } \\
\text { Cu-63 (n,a) Co-60 }\end{array}$ & $\begin{array}{l}0.000 \\
0.000 \\
0.000 \\
0.000\end{array}$ & $\begin{array}{l}9.740 \\
9.740 \\
9.740 \\
9.740\end{array}$ & $\begin{array}{r}-23.850 \\
-23.850 \\
-23.850 \\
-23.85\end{array}$ & $\begin{array}{l}3.45 E+02 \\
5.74 E+02 \\
3.27 E+02 \\
3.75 E+00\end{array}$ \\
\hline $\begin{array}{l}\text { GS20-Co } \\
\text { GS20-Ag } \\
\text { GS20-Fe } \\
\text { GS20-Cu }\end{array}$ & $\begin{array}{l}\text { Co-59 (n,g) Co-60 } \\
\text { Ag-109 (n,g) Ag-110m } \\
\text { Fe-54 (n,p) Mn-54 } \\
\text { Cu-63 (n,a) Co-60 }\end{array}$ & $\begin{array}{l}-10.300 \\
-10.300 \\
-10.300 \\
-10.300\end{array}$ & $\begin{array}{l}9.740 \\
9.740 \\
9.740 \\
9.740\end{array}$ & $\begin{array}{l}23.780 \\
23.780 \\
23.780 \\
23.780\end{array}$ & $\begin{array}{l}3.93 E+02 \\
6.05 E+02 \\
3.04 E+02 \\
3.65 E+00\end{array}$ \\
\hline
\end{tabular}


Table A.1 (continued)

\begin{tabular}{|c|c|c|c|c|c|}
\hline \multirow{2}{*}{$\begin{array}{l}\text { Monitor } \\
\text { ID }\end{array}$} & \multirow[t]{2}{*}{ Reaction } & \multicolumn{3}{|c|}{ Coordinates } & \multirow{2}{*}{$\begin{array}{l}\text { Activity* } \\
\text { at EOI } \\
\text { (Bq/mg) }\end{array}$} \\
\hline & & $\underset{(\mathrm{cm})}{X}$ & $\begin{array}{c}Y \\
(\mathrm{~cm})\end{array}$ & $\underset{(\mathrm{cm})}{Z}$ & \\
\hline $\begin{array}{l}\text { GS21-Co } \\
\text { GS21-Ag } \\
\text { GS21-Fe } \\
\text { GS21-Cu }\end{array}$ & $\begin{array}{l}\mathrm{Co-59}(n, g) \mathrm{Co}-60 \\
\mathrm{Ag}-109(n, g) \mathrm{Ag}-110 \mathrm{~m} \\
\mathrm{Fe}-54(n, p) \mathrm{Mn}-54 \\
\mathrm{Cu}-63(n, a) \mathrm{Co}-60\end{array}$ & $\begin{array}{l}-10.300 \\
-10.300 \\
-10.300 \\
-10.300\end{array}$ & $\begin{array}{l}9.740 \\
9.740 \\
9.740 \\
9.740\end{array}$ & $\begin{array}{l}-0.030 \\
-0.030 \\
-0.030 \\
-0.030\end{array}$ & $\begin{array}{l}5.88 E+02 \\
8.92 E+02 \\
4.41 E+02 \\
5.29 E+00\end{array}$ \\
\hline $\begin{array}{l}\text { GS22-Co } \\
\text { GS22-Ag } \\
\text { GS22-Fe } \\
\text { GS22-Cu }\end{array}$ & $\begin{array}{l}\text { Co-59 }(n, g) \text { Co-60 } \\
\text { Ag-109 (n,g) Ag-110m } \\
\text { Fe-54 (n,p) Mn-54 } \\
\text { Cu-63 (n,a) Co-60 }\end{array}$ & $\begin{array}{l}-10.300 \\
-10.300 \\
-10.300 \\
-10.300\end{array}$ & $\begin{array}{l}9.740 \\
9.740 \\
9.740 \\
9.740\end{array}$ & $\begin{array}{l}-23.850 \\
-23.850 \\
-23.850 \\
-23.850\end{array}$ & $\begin{array}{l}2.98 E+02 \\
4.21 E+02 \\
2.19 E+02 \\
2.62 E+00\end{array}$ \\
\hline $\begin{array}{l}\text { FRDS-A-Co } \\
\text { FRDS-A-Ag } \\
\text { FRDS-A-Np } \\
\text { FRDS-A-Np } \\
\text { FRDS-A-Np } \\
\text { FRDS-A-Np } \\
\text { FRDS-A-Np } \\
\text { FRDS-A-U } \\
\text { FRDS-A-U } \\
\text { FRDS-A-U } \\
\text { FRDS-A-U } \\
\text { FRDS-A-U } \\
\text { FRDS-A-Ni } \\
\text { FRDS-A-Fe } \\
\text { FRDS-A-Ti } \\
\text { FRDS-A-Cu }\end{array}$ & $\begin{array}{l}\text { Co-59 (n,g) Co-60 } \\
\text { Ag-109 (n,g) Ag-110m } \\
\text { Np-237 (n,f) Zr-95 } \\
\text { Np-237 (n,f) Ru-103 } \\
\text { Np-237 (n,f) Ru-106 } \\
\text { Np-237 (n,f) Cs-137 } \\
\text { Np-237 (n,f) Ce-144 } \\
\text { U-238 (n,f) Zr-95 } \\
\text { U-238 (n,f) Ru-103 } \\
\text { U-238 (n,f) Ru-106 } \\
\text { U-238 (n,f) Cs-137 } \\
\text { U-238 (n,f) Ce-144 } \\
\text { Ni-58 (n,p) Co-58 } \\
\text { Fe-54 (n,p) Mn-54 } \\
\text { Ti-46 (n,p) Sc-46 } \\
\text { Cu-63 (n,a) Co-60 }\end{array}$ & $\begin{array}{l}-10.300 \\
-10.300 \\
-10.300 \\
-10.300 \\
-10.300 \\
-10.300 \\
-10.300 \\
-10.300 \\
-10.300 \\
-10.300 \\
-10.300 \\
-10.300 \\
-10.300 \\
-10.300 \\
-10.300 \\
-10.300\end{array}$ & $\begin{array}{l}2.250 \\
2.250 \\
2.250 \\
2.250 \\
2.250 \\
2.250 \\
2.250 \\
2.250 \\
2.250 \\
2.250 \\
2.250 \\
2.250 \\
2.250 \\
2.250 \\
2.250 \\
2.250\end{array}$ & $\begin{array}{l}23.780 \\
23.780 \\
23.780 \\
23.780 \\
23.780 \\
23.780 \\
23.780 \\
23.780 \\
23.780 \\
23.780 \\
23.780 \\
23.780 \\
23.780 \\
23.780 \\
23.780 \\
23.780\end{array}$ & $\begin{array}{l}5.10 E+02 \\
1.67 E+03 \\
3.16 E+04 \\
4.60 E+04 \\
2.55 E+03 \\
2.76 E+02 \\
6.14 E+03 \\
5.91 E+03 \\
1.02 E+04 \\
7.04 E+02 \\
5.53 E+01 \\
1.59 E+03 \\
8.10 E+04 \\
1.45 E+03 \\
1.07 E+03 \\
1.68 E+01\end{array}$ \\
\hline $\begin{array}{l}\text { FRDS-B-Co } \\
\text { FRDS-B-Ag } \\
\text { FRDS-B-Np } \\
\text { FRDS-B-Np } \\
\text { FRDS-B-Np } \\
\text { FRDS-B-Np } \\
\text { FRDS-B-Np } \\
\text { FRDS-B-U } \\
\text { FRDS-B-U } \\
\text { FRDS-B-U } \\
\text { FRDS-B-U } \\
\text { FRDS-B-U } \\
\text { FRDS-B-Ni } \\
\text { FRDS-B-Fe } \\
\text { FRDS-B-Ti } \\
\text { FRDS-B-Cu }\end{array}$ & $\begin{array}{l}\text { Co-59 (n,g) Co-60 } \\
\text { Ag-109 (n,g) Ag-110m } \\
\text { Np-237 (n,f) Zr-95 } \\
\text { Np-237 (n,f) Ru-103 } \\
\text { Np-237 (n,f) Ru-106 } \\
\text { Np-237 (n,f) Cs-137 } \\
\text { Np-237 (n,f) Ce-144 } \\
\text { U-238 (n,f) Zr-95 } \\
\text { U-238 (n,f) Ru-103 } \\
\text { U-238 (n,f) Ru-106 } \\
\text { U-238 (n,f) Cs-137 } \\
\text { U-238 (n,f) Ce-144 } \\
\text { Ni-58 (n,p) Co-58 } \\
\text { Fe-54 (n,p) Mn-54 } \\
\text { Ti-46 (n,p) Sc-46 } \\
\text { Cu-63 (n,a) Co-60 }\end{array}$ & $\begin{array}{l}-10.300 \\
-10.300 \\
-10.300 \\
-10.300 \\
-10.300 \\
-10.300 \\
-10.300 \\
-10.300 \\
-10.300 \\
-10.300 \\
-10.300 \\
-10.300 \\
-10.300 \\
-10.300 \\
-10.300 \\
-10.300\end{array}$ & $\begin{array}{l}2.250 \\
2.250 \\
2.250 \\
2.250 \\
2.250 \\
2.250 \\
2.250 \\
2.250 \\
2.250 \\
2.250 \\
2.250 \\
2.250 \\
2.250 \\
2.250 \\
2.250 \\
2.250\end{array}$ & $\begin{array}{l}-0.030 \\
-0.030 \\
-0.030 \\
-0.030 \\
-0.030 \\
-0.030 \\
-0.030 \\
-0.030 \\
-0.030 \\
-0.030 \\
-0.030 \\
-0.030 \\
-0.030 \\
-0.030 \\
-0.030 \\
-0.030\end{array}$ & $\begin{array}{l}7.70 E+02 \\
2.54 E+03 \\
5.62 E+04 \\
8.12 E+04 \\
4.67 E+03 \\
5.06 E+02 \\
1.08 E+04 \\
8.33 E+03 \\
1.43 E+04 \\
9.92 E+02 \\
7.94 E+01 \\
2.16 E+03 \\
1.18 E+05 \\
2.08 E+03 \\
1.54 E+03 \\
2.42 E+01\end{array}$ \\
\hline $\begin{array}{l}\text { FRDS-C-Co } \\
\text { FRDS-C-Ag } \\
\text { FRDS-C-Np } \\
\text { FRDS-C-Np } \\
\text { FRDS-C-Np } \\
\text { FRDS-C-Np } \\
\text { FRDS-C-Np }\end{array}$ & $\begin{array}{l}\mathrm{Co-59}(n, g) \mathrm{Co}-60 \\
\mathrm{Ag}-109(\mathrm{n}, \mathrm{g}) \mathrm{Ag}-110 \mathrm{~m} \\
\mathrm{~Np}-237(n, f) \mathrm{Zr}-95 \\
\mathrm{~Np}-237(n, f) \text { Ru-103 } \\
\mathrm{Np}-237(n, f) \mathrm{Ru}-106 \\
\mathrm{~Np}-237(n, f) \mathrm{Cs}-137 \\
\mathrm{~Np}-237(n, f) \mathrm{Ce}-144\end{array}$ & $\begin{array}{l}0.000 \\
0.000 \\
0.000 \\
0.000 \\
0.000 \\
0.000 \\
0.000\end{array}$ & $\begin{array}{l}2.250 \\
2.250 \\
2.250 \\
2.250 \\
2.250 \\
2.250 \\
2.250\end{array}$ & $\begin{array}{l}-0.030 \\
-0.030 \\
-0.030 \\
-0.030 \\
-0.030 \\
-0.030 \\
-0.030\end{array}$ & $\begin{array}{l}1.23 E+03 \\
4.00 E+03 \\
9.90 E+04 \\
1.44 E+05 \\
7.87 E+03 \\
9.02 E+02 \\
2.01 E+04\end{array}$ \\
\hline
\end{tabular}


Table A.1 (continued)

\begin{tabular}{|c|c|c|c|c|c|}
\hline \multirow{2}{*}{$\begin{array}{l}\text { Monitor } \\
\text { ID }\end{array}$} & \multirow[t]{2}{*}{ Reaction } & \multicolumn{3}{|c|}{ Coordinates } & \multirow{2}{*}{$\begin{array}{l}\text { Activity* }^{*} \\
\text { at EOI } \\
\text { (Bq/mg) }\end{array}$} \\
\hline & & $\underset{(\mathrm{cm})}{X}$ & $\begin{array}{c}Y \\
(\mathrm{~cm})\end{array}$ & $\underset{(\mathrm{cm})}{Z}$ & \\
\hline $\begin{array}{l}\text { FRDS-C-U } \\
\text { FRDS-C-U } \\
\text { FRDS-C-U } \\
\text { FRDS-C-U } \\
\text { FRDS-C-U } \\
\text { FRDS-C-Ni } \\
\text { FRDS-C-Fe } \\
\text { FRDS-C-Ti } \\
\text { FRDS-C-Cu }\end{array}$ & $\begin{array}{l}\text { U-238 (n,f) Zr-95 } \\
\text { U-238 (n,f) Ru-103 } \\
\text { U-238 (n,f) Ru-106 } \\
\text { U-238 (n,f) Cs-137 } \\
\text { U-238 (n,f) Ce-144 } \\
\text { Ni-58 (n,p) Co-58 } \\
\text { Fe-54 (n,p) Mn-54 } \\
\text { Ti-46 }(n, p) \text { Sc-46 } \\
\text { Cu-63 (n,a) Co-60 }\end{array}$ & $\begin{array}{l}0.000 \\
0.000 \\
0.000 \\
0.000 \\
0.000 \\
0.000 \\
0.000 \\
0.000 \\
0.000\end{array}$ & $\begin{array}{l}2.250 \\
2.250 \\
2.250 \\
2.250 \\
2.250 \\
2.250 \\
2.250 \\
2.250 \\
2.250\end{array}$ & $\begin{array}{l}-0.030 \\
-0.030 \\
-0.030 \\
-0.030 \\
-0.030 \\
-0.030 \\
-0.030 \\
-0.030 \\
-0.030\end{array}$ & $\begin{array}{l}1.31 E+04 \\
2.29 E+04 \\
1.51 E+03 \\
1.22 E+02 \\
3.35 E+03 \\
1.79 E+05 \\
3.15 E+03 \\
2.33 E+03 \\
3.65 E+01\end{array}$ \\
\hline $\begin{array}{l}\text { FRDS-D-Co } \\
\text { FRDS-D-Ag } \\
\text { FRDS-D-Np } \\
\text { FRDS-D-Np } \\
\text { FRDS-D-Np } \\
\text { FRDS-D-Np } \\
\text { FRDS-D-Np } \\
\text { FRDS-D-U } \\
\text { FRDS-D-U } \\
\text { FRDS-D-U }\end{array}$ & $\begin{array}{l}\text { Co-59 (n,g) Co-60 } \\
\text { Ag-109 (n,g) Ag-110m } \\
\text { Np-237 (n,f) Zr-95 } \\
\text { Np-237 (n,f) Ru-103 } \\
\text { Np-237 (n,f) Ru-106 } \\
\text { Np-237 (n,f) Cs-137 } \\
\text { Np-237 (n,f) Ce-144 } \\
\text { U-238 (n,f) Zr-95 } \\
\text { U-238 (n,f) Ru-103 } \\
\text { U-238 (n,f) Ru-106 }\end{array}$ & $\begin{array}{l}10.300 \\
10.300 \\
10.300 \\
10.300 \\
10.300 \\
10.300 \\
10.300 \\
10.300 \\
10.300 \\
10.300\end{array}$ & $\begin{array}{l}2.250 \\
2.250 \\
2.250 \\
2.250 \\
2.250 \\
2.250 \\
2.250 \\
2.250 \\
2.250 \\
2.250\end{array}$ & $\begin{array}{l}-0.030 \\
-0.030 \\
-0.030 \\
-0.030 \\
-0.030 \\
-0.030 \\
-0.030 \\
-0.030 \\
-0.030 \\
-0.030\end{array}$ & $\begin{array}{l}1.19 E+03 \\
3.93 E+03 \\
1.00 E+05 \\
1.46 E+05 \\
8.06 E+03 \\
8.84 E+02 \\
1.86 E+04 \\
1.36 E+04 \\
2.37 E+04 \\
1.60 E+03\end{array}$ \\
\hline $\begin{array}{l}\text { FRDS-D-U } \\
\text { FRDS-D-U } \\
\text { FRDS-D-Ni } \\
\text { FRDS-D-Fe } \\
\text { FRDS-D-Ti } \\
\text { FRDS-D-Cu }\end{array}$ & $\begin{array}{l}\text { U-238 (n,f) Cs-137 } \\
\text { U-238 (n,f) Ce-144 } \\
\text { Ni-58 (n,p) Co-58 } \\
\text { Fe-54 (n,p) Mn-54 } \\
\text { Ti-46 (n,p) Sc-46 } \\
\text { Cu-63 (n,a) Co-60 }\end{array}$ & $\begin{array}{l}10.300 \\
10.300 \\
10.300 \\
10.300 \\
10.300 \\
10.300\end{array}$ & $\begin{array}{l}2.250 \\
2.250 \\
2.250 \\
2.250 \\
2.250 \\
2.250\end{array}$ & $\begin{array}{l}-0.030 \\
-0.030 \\
-0.030 \\
-0.030 \\
-0.030 \\
-0.030\end{array}$ & $\begin{array}{l}1.28 E+02 \\
3.55 E+03 \\
1.92 E+05 \\
3.41 E+03 \\
2.51 E+03 \\
3.90 E+01\end{array}$ \\
\hline $\begin{array}{l}\text { FRDS-E-Co } \\
\text { FRDS-E-Ag } \\
\text { FRDS-E-Np } \\
\text { FRDS-E-Np } \\
\text { FRDS-E-Np } \\
\text { FRDS-E-Np } \\
\text { FRDS-E-Np } \\
\text { FRDS-E-U } \\
\text { FRDS-E-U } \\
\text { FRDS-E-U } \\
\text { FRDS-E-U } \\
\text { FRDS-E-U } \\
\text { FRDS-E-Ni } \\
\text { FRDS-E-Fe } \\
\text { FRDS-E-Ti } \\
\text { FRDS-E-Cu }\end{array}$ & 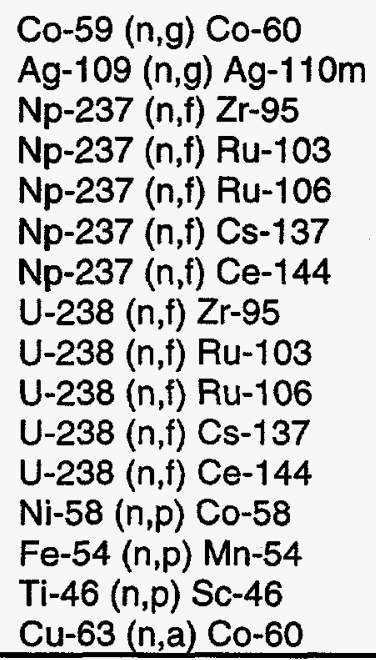 & $\begin{array}{l}0.000 \\
0.000 \\
0.000 \\
0.000 \\
0.000 \\
0.000 \\
0.000 \\
0.000 \\
0.000 \\
0.000 \\
0.000 \\
0.000 \\
0.000 \\
0.000 \\
0.000 \\
0.000\end{array}$ & $\begin{array}{l}5.990 \\
5.990 \\
5.990 \\
5.990 \\
5.990 \\
5.990 \\
5.990 \\
5.990 \\
5.990 \\
5.990 \\
5.990 \\
5.990 \\
5.990 \\
5.990 \\
5.990 \\
5.990 \\
\end{array}$ & $\begin{array}{l}-0.030 \\
-0.030 \\
-0.030 \\
-0.030 \\
-0.030 \\
-0.030 \\
-0.030 \\
-0.030 \\
-0.030 \\
-0.030 \\
-0.030 \\
-0.030 \\
-0.030 \\
-0.030 \\
-0.030 \\
-0.030 \\
\end{array}$ & $\begin{array}{l}6.64 \mathrm{E}+02 \\
2.02 \mathrm{E}+03 \\
6.11 \mathrm{E}+04 \\
8.73 \mathrm{E}+04 \\
4.78 \mathrm{E}+03 \\
5.39 \mathrm{E}+02 \\
1.08 \mathrm{E}+04 \\
6.63 \mathrm{E}+03 \\
1.17 \mathrm{E}+04 \\
7.78 \mathrm{E}+02 \\
6.25 \mathrm{E}+01 \\
1.69 \mathrm{E}+03 \\
8.35 \mathrm{E}+04 \\
1.44 \mathrm{E}+03 \\
1.03 \mathrm{E}+03 \\
1.54 \mathrm{E}+01\end{array}$ \\
\hline
\end{tabular}

*For the $\mathrm{Co}$ and $\mathrm{Ag}$ monitors, diluted materials in form of Al alloys were used. Co (Al) was with Co content of $0.1 \%$ by weight, and $\mathrm{Ag}$ (Al) alloy was with $\mathrm{Ag}$ content of $0.173 \%$ by weight. Activities listed are per milligram of alloy. The fission product activities in ${ }^{237} \mathrm{~Np}$ and ${ }^{238} \mathrm{U}$ monitors are given per milligram of ${ }^{237} \mathrm{~Np}$ and ${ }^{238} \mathrm{U}$, respectively. Activities of all other monitors are given per milligram of chemically pure target material.

${ }^{t} E O I=$ end of irradiation.

**Monitor lost. 
Table A.2. Irradiation history for HSSI 10.0D dosimetry capsule

\begin{tabular}{lllll}
\hline \multicolumn{2}{c}{ Beginning } & \multicolumn{2}{c}{ End } & \multicolumn{1}{c}{$\begin{array}{c}\text { Fraction of } \\
\text { full power }\end{array}$} \\
\hline & time & date & time & Cycle 338B \\
02/18/92 & $16: 03$ & $02 / 18 / 92$ & $16: 23$ & 0.005 \\
$02 / 18 / 92$ & $16: 23$ & $02 / 19 / 92$ & $10: 51$ & 0.0 \\
$02 / 19 / 92$ & $10: 51$ & $02 / 28 / 92$ & $13: 05$ & 1.0 \\
$02 / 28 / 92$ & $13: 05$ & $03 / 17 / 92$ & $14: 46$ & 0.0 \\
& & & & \\
$03 / 17 / 92$ & $14: 46$ & $03 / 18 / 92$ & $10: 05$ & 1.0 \\
$03 / 18 / 92$ & $10: 05$ & $03 / 18 / 92$ & $10: 25$ & 0.0 \\
$03 / 18 / 92$ & $10: 25$ & $03 / 26 / 92$ & $08: 49$ & 1.0 \\
$03 / 26 / 92$ & $08: 49$ & $03 / 31 / 92$ & $12: 16$ & 0.0 \\
& & & & \\
$03 / 31 / 92$ & $12: 16$ & $04 / 07 / 92$ & $08: 45$ & 1.0 \\
$04 / 07 / 92$ & $08: 45$ & $04 / 07 / 92$ & $15: 47$ & 0.0 \\
$04 / 07 / 92$ & $15: 47$ & $04 / 08 / 92$ & $07: 55$ & 1.0 \\
$04 / 08 / 92$ & $07: 55$ & $04 / 08 / 92$ & $16: 47$ & 0.0 \\
$04 / 08 / 92$ & $16: 47$ & $04 / 09 / 92$ & $23: 45$ & 1.0 \\
$04 / 09 / 92$ & $23: 45$ & & & 0.0 \\
\hline
\end{tabular}

*Full power is $2 \mathrm{MW}$.

${ }^{+}$Cycle 338B effective full-power time: $7.85646 \mathrm{E}+5 \mathrm{~s}$.

${ }^{\star *}$ Cycle 339B effective full-power time: $7.54980 \mathrm{E}+5 \mathrm{~s}$.

ttCycle 340A effective full-power time: $7.61700 \mathrm{E}+5 \mathrm{~s}$. 
Table A.3. Specific activities of the removable dosimeter tube (RDT) dosimeters in the HSSI 10.0D experiment at the end of irradiation (EOI)

\begin{tabular}{|c|c|c|c|c|c|c|}
\hline \multirow[t]{2}{*}{ Reaction } & \multicolumn{3}{|c|}{ Coordinates } & & \multicolumn{2}{|c|}{ Specific activity at EOI } \\
\hline & $\begin{array}{c}X \\
(\mathrm{~cm})\end{array}$ & $\begin{array}{c}Y \\
(\mathrm{~cm})\end{array}$ & $\begin{array}{c}\mathrm{Z} \\
(\mathrm{cm})\end{array}$ & Cy $338 B$ & $\begin{array}{l}\text { Су } 339 \mathrm{~B} \\
(\mathrm{~Bq} / \mathrm{mg})\end{array}$ & Cy $340 A$ \\
\hline & & & & RDT1 & RDT4 & RDT6 \\
\hline $\begin{array}{l}F e-54 \text { (n,p) Mn-54 } \\
\text { Fe-54 (n,p) Mn-54 } \\
\text { Fe-54 (n,p) Mn-54 } \\
\text { Fe-54 (n,p) Mn-54 } \\
\text { Fe-54 (n,p) Mn-54 } \\
\text { Fe-54 (n,p) Mn-54 }\end{array}$ & $\begin{array}{l}-17.14 \\
-17.14 \\
-17.14 \\
-17.14 \\
-17.14 \\
-17.14\end{array}$ & $\begin{array}{l}-0.96 \\
-0.96 \\
-0.96 \\
-0.96 \\
-0.96 \\
-0.96\end{array}$ & $\begin{array}{r}24.13 \\
13.97 \\
3.81 \\
-3.81 \\
-13.97 \\
-24.13\end{array}$ & $\begin{array}{l}450 \\
622 \\
723 \\
707 \\
595 \\
386\end{array}$ & $\begin{array}{l}423 \\
601 \\
665 \\
672 \\
556 \\
344\end{array}$ & $\begin{array}{l}439 \\
606 \\
670 \\
658 \\
574 \\
364\end{array}$ \\
\hline $\begin{array}{l}\text { Co-59 }(n, g) \text { Co-60 } \\
\text { Co-59 }(n, g) \text { Co-60 } \\
\text { Co-59 }(n, g) \text { Co-60 } \\
\text { Co-59 }(n, g) \text { Co-60 } \\
\text { Co-59 }(n, g) \text { Co-60 } \\
\text { Co-59 }(n, g) \text { Co-60 }\end{array}$ & $\begin{array}{l}-17.14 \\
-17.14 \\
-17.14 \\
-17.14 \\
-17.14 \\
-17.14\end{array}$ & $\begin{array}{l}-0.96 \\
-0.96 \\
-0.96 \\
-0.96 \\
-0.96 \\
-0.96\end{array}$ & $\begin{array}{r}24.13 \\
13.97 \\
3.81 \\
-3.81 \\
-13.97 \\
-24.13\end{array}$ & $\begin{array}{l}2060 \\
3720 \\
4180 \\
4110 \\
3420 \\
2220\end{array}$ & $\begin{array}{l}1880 \\
3490 \\
3890 \\
3890 \\
3260 \\
2070\end{array}$ & $\begin{array}{l}1980 \\
3500 \\
3980 \\
3970 \\
3280 \\
2140\end{array}$ \\
\hline & & & & RDT2 & RDT3 & RDT5 \\
\hline $\begin{array}{l}\mathrm{Fe}-54(n, p) \mathrm{Mn}-54 \\
\mathrm{Fe}-54(n, p) \mathrm{Mn}-54 \\
\mathrm{Fe}-54(n, p) \mathrm{Mn}-54\end{array}$ & $\begin{array}{l}17.14 \\
17.14 \\
17.14\end{array}$ & $\begin{array}{l}-0.96 \\
-0.96 \\
-0.96\end{array}$ & $\begin{array}{r}24.13 \\
13.97 \\
3.81\end{array}$ & $\begin{array}{r}856 \\
1250 \\
1410\end{array}$ & $\begin{array}{r}983 \\
1410 \\
1560\end{array}$ & $\begin{array}{l}1100 \\
1600 \\
1810\end{array}$ \\
\hline $\begin{array}{l}\mathrm{Fe}-54(n, p) \mathrm{Mn}-54 \\
\mathrm{Fe}-54(n, p) \mathrm{Mn}-54 \\
\mathrm{Fe}-54(n, p) \text { Mn-54 }\end{array}$ & $\begin{array}{l}17.14 \\
17.14 \\
17.14\end{array}$ & $\begin{array}{l}-0.96 \\
-0.96 \\
-0.96\end{array}$ & $\begin{array}{r}-3.81 \\
-13.97 \\
-24.13\end{array}$ & $\begin{array}{r}1390 \\
1180 \\
753\end{array}$ & $\begin{array}{r}1540 \\
1340 \\
851\end{array}$ & $\begin{array}{r}1780 \\
1550 \\
975\end{array}$ \\
\hline $\begin{array}{l}\text { Co-59 }(n, g) \text { Co-60 } \\
\text { Co-59 }(n, g) \text { Co-60 } \\
\text { Co-59 }(n, g) \text { Co-60 } \\
\text { Co-59 }(n, g) \text { Co-60 } \\
\text { Co-59 }(n, g) \text { Co-60 } \\
\text { Co-59 }(n, g) \text { Co-60 }\end{array}$ & $\begin{array}{l}17.14 \\
17.14 \\
17.14 \\
17.14 \\
17.14 \\
17.14\end{array}$ & $\begin{array}{l}-0.96 \\
-0.96 \\
-0.96 \\
-0.96 \\
-0.96 \\
-0.96\end{array}$ & $\begin{array}{r}24.13 \\
13.97 \\
3.81 \\
-3.81 \\
-13.97 \\
-24.13\end{array}$ & $\begin{array}{l}2620 \\
4740 \\
5510 \\
5480 \\
4630 \\
2830\end{array}$ & $\begin{array}{l}2860 \\
5070 \\
5990 \\
5960 \\
4960 \\
3170\end{array}$ & $\begin{array}{l}3060 \\
5580 \\
6570 \\
6660 \\
5540 \\
3310\end{array}$ \\
\hline
\end{tabular}


Table A.4. Cycle-to-cycle comparison of specific activities of the removable dosimeter tube (RDT) dosimeters in the HSSI 10.0D experiment at the end of irradiation (EOI)

\begin{tabular}{|c|c|c|c|c|c|c|}
\hline \multirow[t]{2}{*}{ Reaction } & \multicolumn{3}{|c|}{ Coordinates } & \multicolumn{3}{|c|}{ Normalized specific activity at EOI* } \\
\hline & $\underset{(\mathrm{cm})}{X}$ & $\begin{array}{c}\mathrm{Y} \\
(\mathrm{cm})\end{array}$ & $\begin{array}{c}Z \\
(\mathrm{~cm})\end{array}$ & Cy 338B & Cy 339B & Cy $340 \mathrm{~A}$ \\
\hline & & & & RDT1 & RDT4 & RDT6 \\
\hline 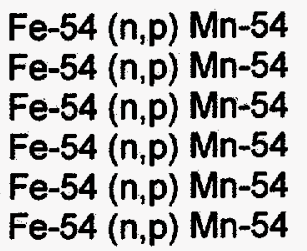 & $\begin{array}{l}-17.1 \\
-17.1 \\
-17.1 \\
-17.1 \\
-17.1 \\
-17.1\end{array}$ & $\begin{array}{l}-0.96 \\
-0.96 \\
-0.96 \\
-0.96 \\
-0.96 \\
-0.96\end{array}$ & $\begin{array}{r}24.13 \\
13.97 \\
3.81 \\
-3.81 \\
-13.97 \\
-24.13\end{array}$ & $\begin{array}{l}1.00 \\
1.00 \\
1.00 \\
1.00 \\
1.00 \\
1.00\end{array}$ & $\begin{array}{l}0.94 \\
0.97 \\
0.92 \\
0.95 \\
0.93 \\
0.89\end{array}$ & $\begin{array}{l}0.98 \\
0.97 \\
0.93 \\
0.93 \\
0.96 \\
0.94\end{array}$ \\
\hline \multirow[t]{2}{*}{$\begin{array}{l}\text { Co-59 (n,g) Co-60 } \\
\text { Co-59 (n,g) Co-60 } \\
\text { Co-59 (n,g) Co-60 } \\
\text { Co-59 (n,g) Co-60 } \\
\text { Co-59 (n,g) Co-60 } \\
\text { Co-59 (n,g) Co-60 }\end{array}$} & $\begin{array}{l}-17.1 \\
-17.1 \\
-17.1 \\
-17.1 \\
-17.1 \\
-17.1\end{array}$ & $\begin{array}{l}-0.96 \\
-0.96 \\
-0.96 \\
-0.96 \\
-0.96 \\
-0.96\end{array}$ & $\begin{array}{r}24.13 \\
13.97 \\
3.81 \\
-3.81 \\
-13.97 \\
-24.13\end{array}$ & $\begin{array}{l}1.00 \\
1.00 \\
1.00 \\
1.00 \\
1.00 \\
1.00\end{array}$ & $\begin{array}{l}0.91 \\
0.94 \\
0.93 \\
0.95 \\
0.95 \\
0.93\end{array}$ & $\begin{array}{l}0.96 \\
0.94 \\
0.95 \\
0.97 \\
0.96 \\
0.96\end{array}$ \\
\hline & & & & RDT2 & RDT3 & RDT5 \\
\hline $\begin{array}{l}\text { Fe-54 (n,p) Mn-54 } \\
\text { Fe-54 (n,p) Mn-54 } \\
\text { Fe-54 (n,p) Mn-54 } \\
\text { Fe-54 (n,p) Mn-54 } \\
\text { Fe-54 (n,p) Mn-54 } \\
\text { Fe-54 (n,p) Mn-54 }\end{array}$ & $\begin{array}{l}17.14 \\
17.14 \\
17.14 \\
17.14 \\
17.14 \\
17.14\end{array}$ & $\begin{array}{l}-0.96 \\
-0.96 \\
-0.96 \\
-0.96 \\
-0.96 \\
-0.96\end{array}$ & $\begin{array}{r}24.13 \\
13.97 \\
3.81 \\
-3.81 \\
-13.97 \\
-24.13\end{array}$ & $\begin{array}{l}1.00 \\
1.00 \\
1.00 \\
1.00 \\
1.00 \\
1.00\end{array}$ & $\begin{array}{l}1.15 \\
1.13 \\
1.11 \\
1.11 \\
1.14 \\
1.13\end{array}$ & $\begin{array}{l}1.29 \\
1.28 \\
1.28 \\
1.28 \\
1.31 \\
1.29\end{array}$ \\
\hline $\begin{array}{l}\text { Co-59 }(n, g) \text { Co-60 } \\
\text { Co-59 }(n, g) \text { Co-60 } \\
\text { Co-59 }(n, g) \text { Co-60 } \\
\text { Co-59 }(n, g) \text { Co-60 } \\
\text { Co-59 }(n, g) \text { Co-60 } \\
\text { Co-59 }(n, g) \text { Co-60 }\end{array}$ & $\begin{array}{l}17.14 \\
17.14 \\
17.14 \\
17.14 \\
17.14 \\
17.14\end{array}$ & $\begin{array}{l}-0.96 \\
-0.96 \\
-0.96 \\
-0.96 \\
-0.96 \\
-0.96\end{array}$ & $\begin{array}{r}24.13 \\
13.97 \\
3.81 \\
-3.81 \\
-13.97 \\
-24.13\end{array}$ & $\begin{array}{l}1.00 \\
1.00 \\
1.00 \\
1.00 \\
1.00 \\
1.00\end{array}$ & $\begin{array}{l}1.09 \\
1.07 \\
1.09 \\
1.09 \\
1.07 \\
1.12\end{array}$ & $\begin{array}{l}1.17 \\
1.18 \\
1.19 \\
1.22 \\
1.20 \\
1.17\end{array}$ \\
\hline
\end{tabular}

*At each location and for each reaction, the specific activities are divided by the specific activity in cycle 338B. 

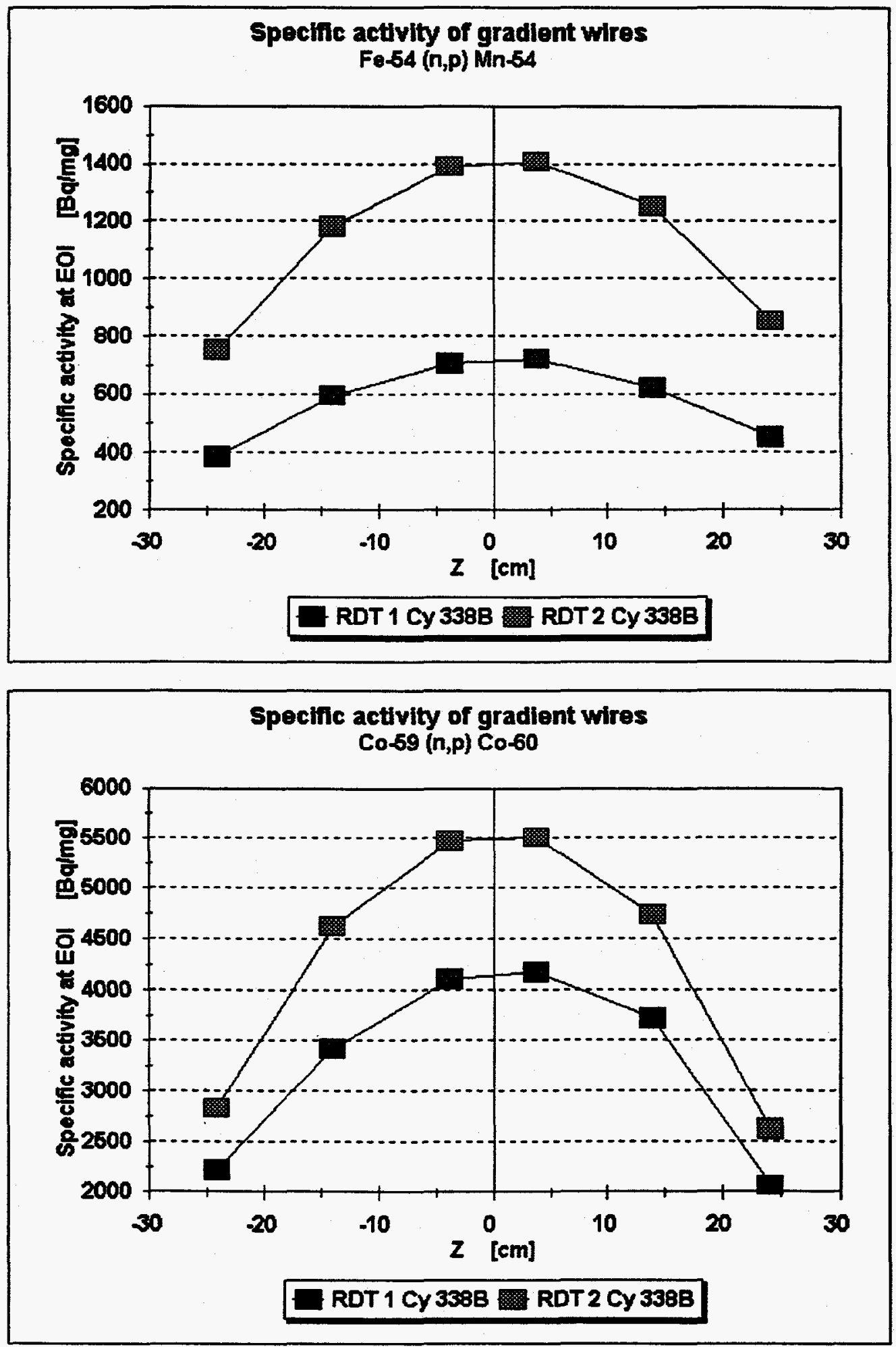

Figure A.1. Measured specific activities of the RDT dosimetry for the cycle 338B vs Z coordinate for (top) iron gradient wires and (bottom) cobalt gradient wires. 

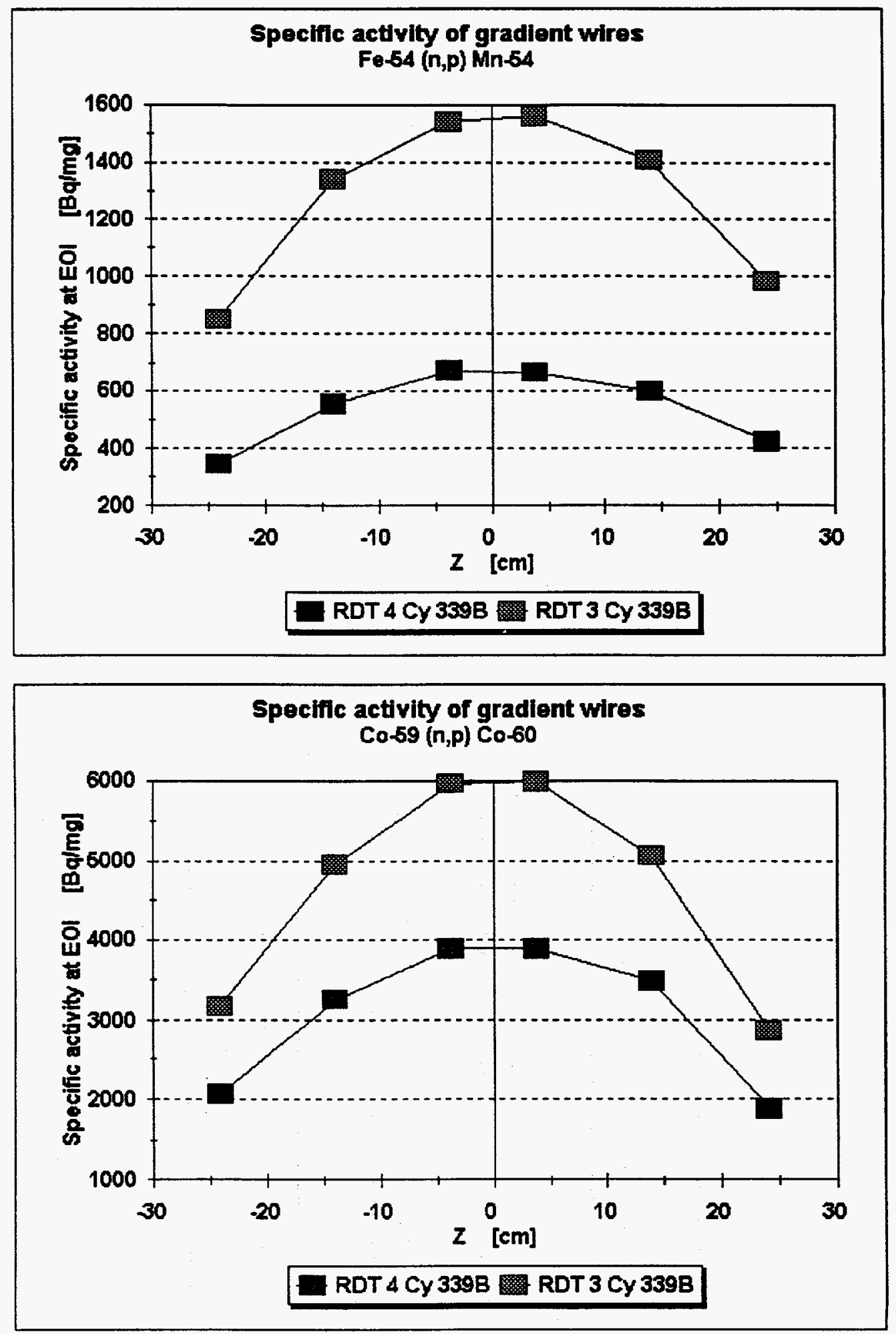

Figure A.2. Measured specific activities of the RDT dosimetry for the cycle 339B vs Z coordinate for (top) iron gradient wires and (bottom) cobalt gradient wires. 

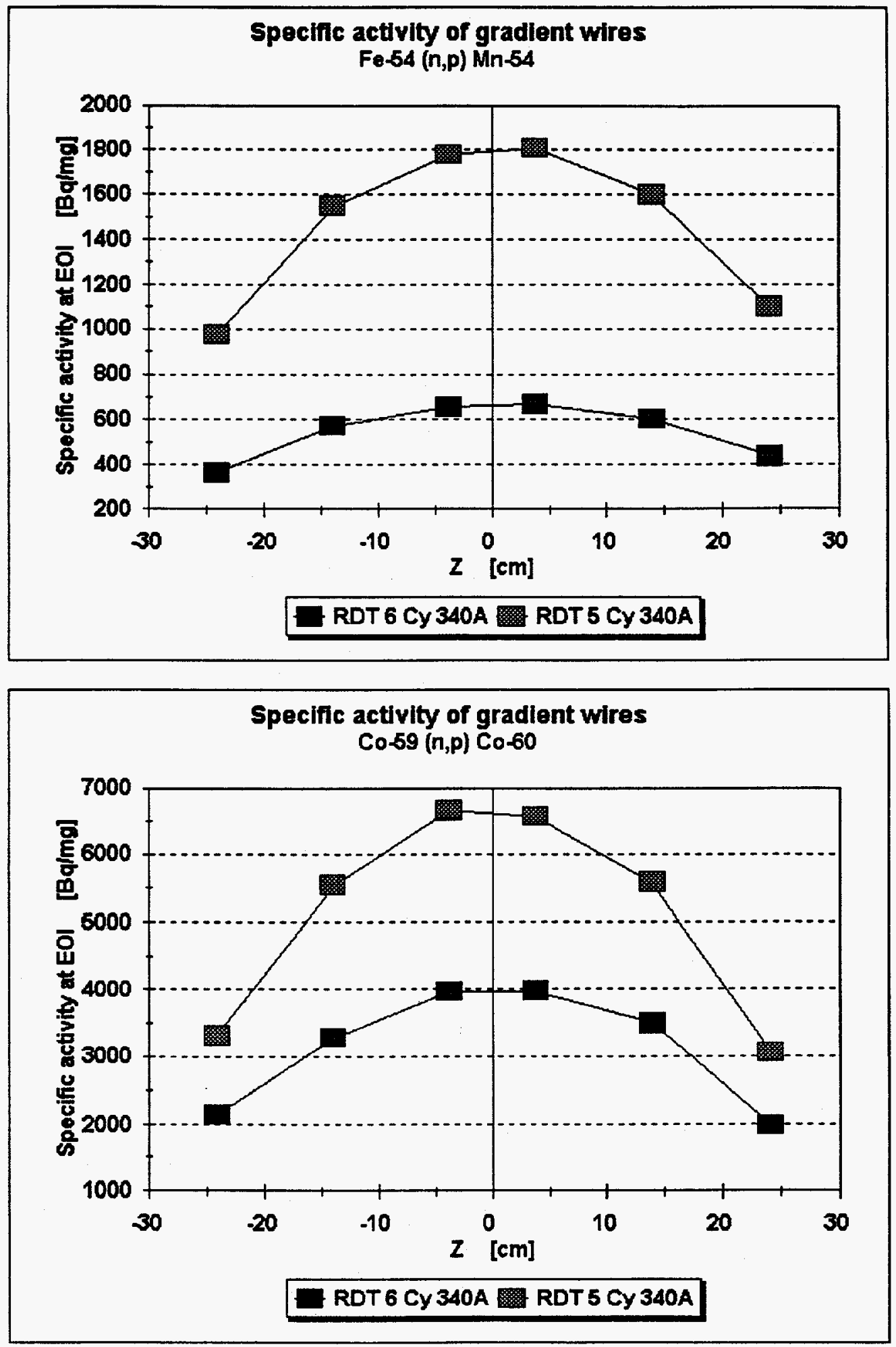

Figure A.3. Measured specific activities of the RDT dosimetry for the cycle 340A vs Z coordinate for (top) iron gradient wires and (bottom) cobalt gradient wires. 

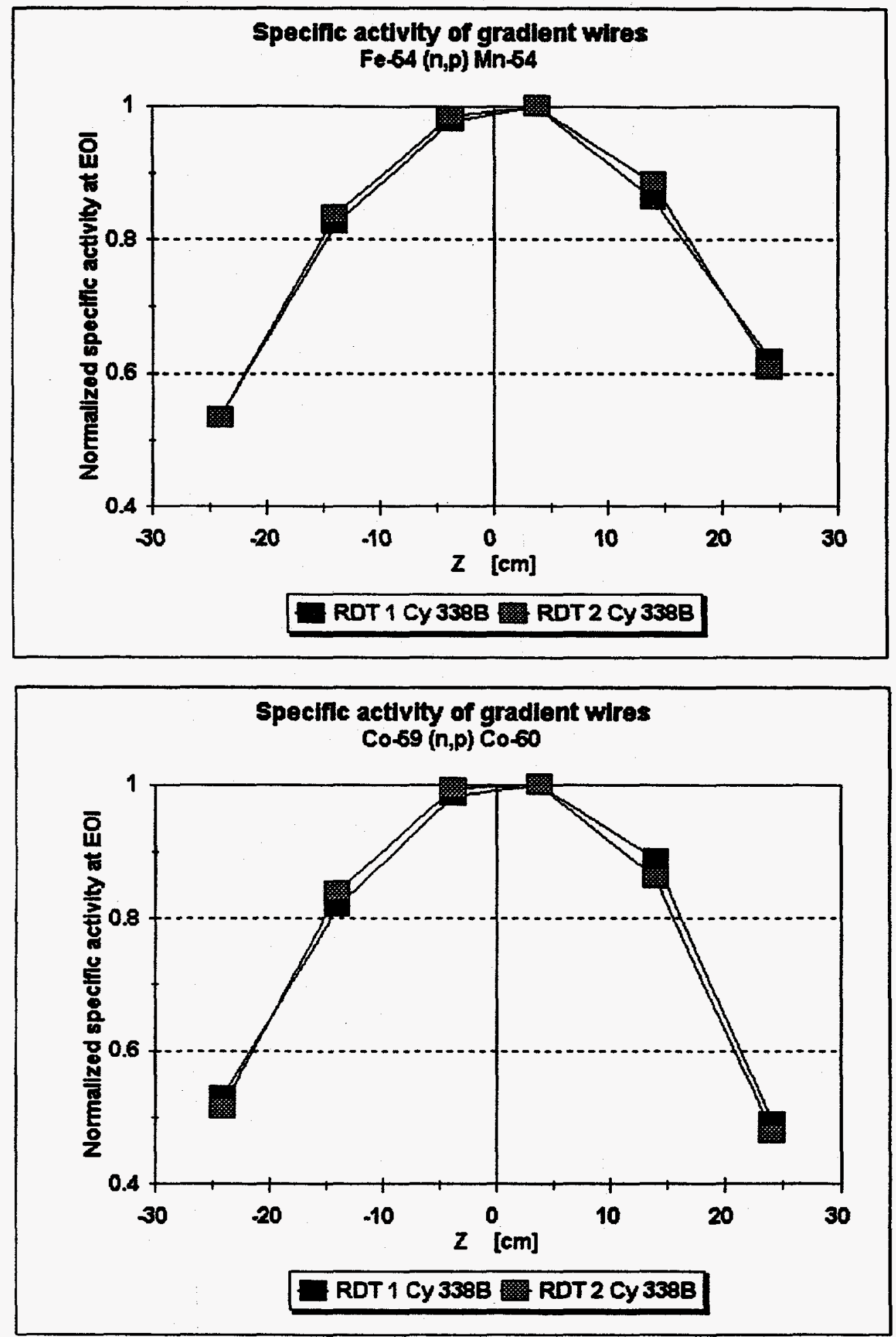

Figure A.4. Normalized measured specific activities of the RDT dosimetry for the cycle $338 B$ vs $Z$ coordinate for (top) iron gradient wires and (bottom) cobalt gradient wires. Normalization is to the maximum value of 1.0 for each reaction and each RDT. 

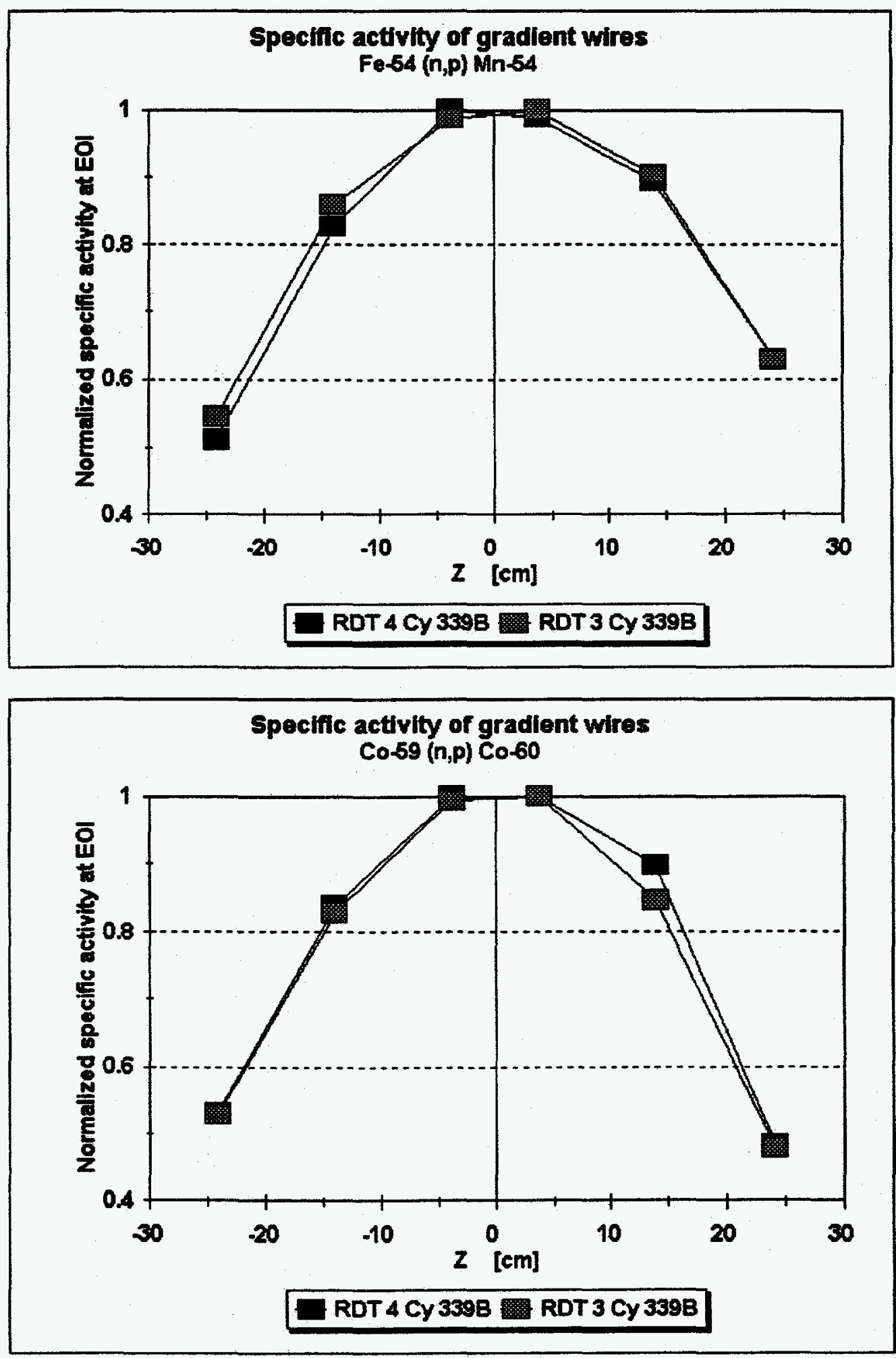

Figure A.5. Normalized measured specific activities of the RDT dosimetry for the cycle 339B vs Z coordinate for (top) iron gradient wires and (bottom) cobalt gradient wires. Values are normalized to the maximum value of 1.0 for each reaction and each RDT. 

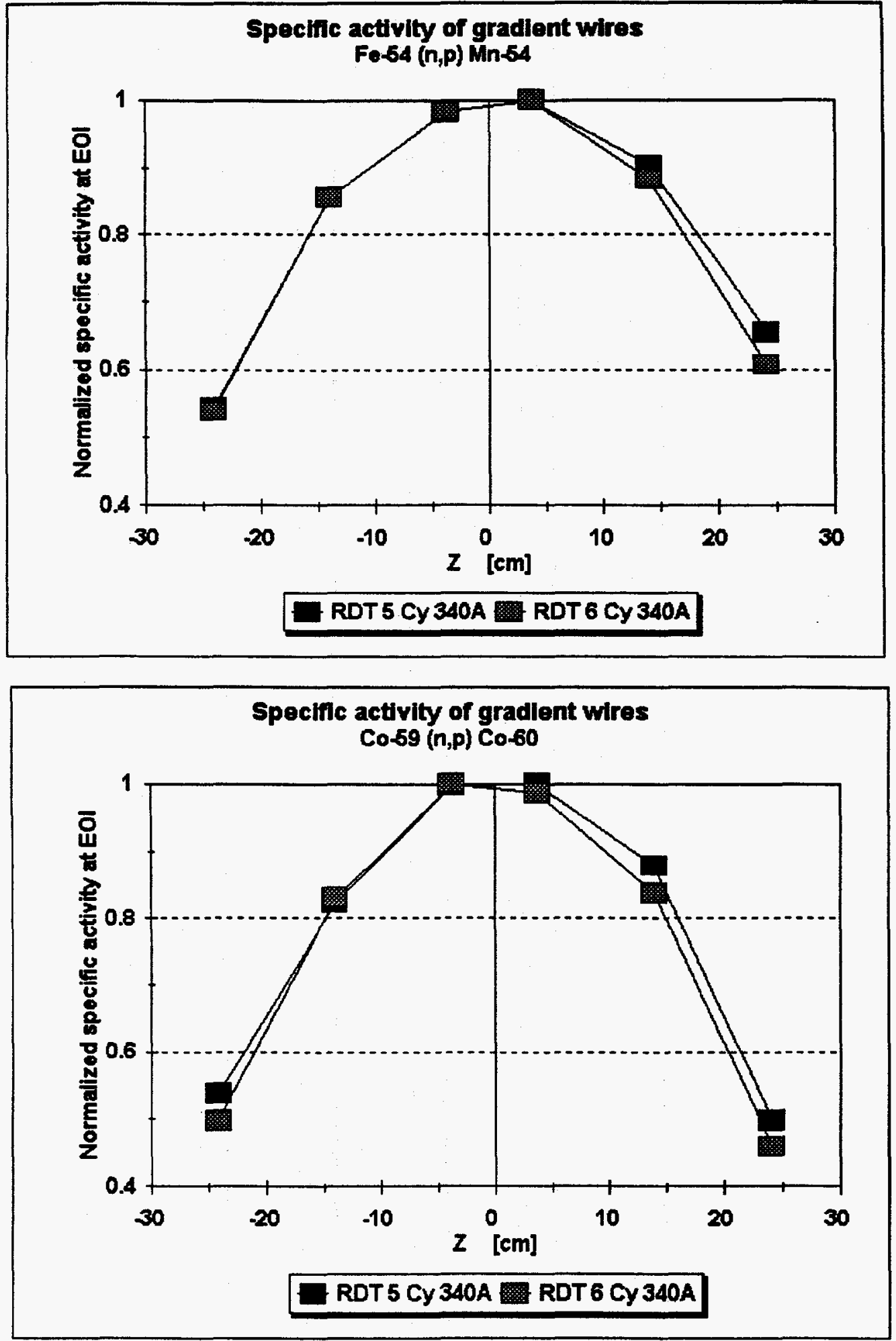

Figure A.6. Normalized measured specific activities of the RDT dosimetry for the cycle $340 \mathrm{~A}$ vs $\mathrm{Z}$ coordinate for (top) iron gradient wires and (bottom) cobalt gradient wires. Values are normalized to the maximum value of 1.0 for each reaction and each RDT. 
Table A.5. Comparison of the adjusted fast fluence rates, $F_{E>1 \text { Mov, }}$ with values obtained from three-dimensional (3-D) fit. Adjusted flux values are averages of the cycles 338B, 339B, and $340 \mathrm{~A}$

\begin{tabular}{|c|c|c|c|c|c|c|}
\hline \multirow[t]{2}{*}{ Location } & \multicolumn{3}{|c|}{ Coordinates } & \multicolumn{2}{|c|}{$F_{E>1 \mathrm{MeV}}$} & \multirow{2}{*}{$\begin{array}{c}\text { Difference } \\
(\%)\end{array}$} \\
\hline & $\begin{array}{c}X \\
(\mathrm{~cm})\end{array}$ & $\begin{array}{c}Y \\
(\mathrm{~cm})\end{array}$ & $\underset{(\mathrm{cm})}{Z}$ & $\begin{array}{l}\text { Adjusted } \\
\left(\mathrm{cm}^{-2} \mathrm{~s}^{-1}\right)\end{array}$ & $\begin{array}{l}\text { 3-D fitted } \\
\left(\mathrm{cm}^{-2} \mathrm{~s}^{-1}\right)\end{array}$ & \\
\hline P23 & -10.30 & 2.25 & 23.78 & $5.017 E+11$ & $4.921 E+11$ & 1.9 \\
\hline $\mathrm{P} 2$ & 0.00 & 2.25 & 23.78 & $7.866 \mathrm{E}+11$ & $7.894 E+11$ & -0.4 \\
\hline P4 & 10.30 & 2.25 & 23.78 & $7.862 E+11$ & $7.870 E+11$ & -0.1 \\
\hline P11 & -10.30 & 5.99 & 23.78 & $2.689 E+11$ & $2.598 E+11$ & 3.4 \\
\hline P9 & 0.00 & 5.99 & 23.78 & $4.250 E+11$ & $4.168 E+11$ & 1.9 \\
\hline P6 & 10.30 & 5.99 & 23.78 & $4.044 E+11$ & $4.155 E+11$ & -2.7 \\
\hline P20 & -10.30 & 9.74 & 23.78 & $1.392 E+11$ & $1.369 E+11$ & 1.6 \\
\hline $\mathrm{P} 17$ & 0.00 & 9.74 & 23.78 & $2.195 E+11$ & 2.197E+11 & -0.1 \\
\hline P14 & 10.30 & 9.74 & 23.78 & $2.060 E+11$ & $2.190 E+11$ & -6.3 \\
\hline$P 24$ & -10.30 & 2.25 & -0.03 & $7.975 E+11$ & $8.142 E+11$ & -2.1 \\
\hline P25 & 0.00 & 2.25 & -0.03 & $1.295 E+12$ & $1.306 E+12$ & -0.9 \\
\hline P26 & 10.30 & 2.25 & -0.03 & $1.320 E+12$ & $1.302 E+12$ & 1.3 \\
\hline P12 & -10.30 & 5.99 & -0.03 & $4.391 E+11$ & $4.299 E+11$ & 2.1 \\
\hline $\mathrm{P} 27$ & 0.00 & 5.99 & -0.03 & $7.084 E+11$ & $6.897 E+11$ & 2.6 \\
\hline P7 & 10.30 & 5.99 & -0.03 & $6.780 E+11$ & $6.876 E+11$ & -1.4 \\
\hline P21 & -10.30 & 9.74 & -0.03 & $2.298 E+11$ & $2.266 \mathrm{E}+11$ & 1.4 \\
\hline P18 & 0.00 & 9.74 & -0.03 & $3.678 E+11$ & $3.636 E+11$ & 1.2 \\
\hline P15 & 10.30 & 9.74 & -0.03 & $3.453 E+11$ & $3.624 E+11$ & -4.9 \\
\hline P1 & -10.30 & 2.25 & -23.85 & $3.710 E+11$ & $3.705 E+11$ & 0.1 \\
\hline P3 & 0.00 & 2.25 & -23.85 & $5.885 E+11$ & $5.944 \mathrm{E}+11$ & -1.0 \\
\hline P 5 & 10.30 & 2.25 & -23.85 & $5.933 E+11$ & $5.926 E+11$ & 0.1 \\
\hline P13 & -10.30 & 5.99 & -23.85 & $2.024 E+11$ & $1.956 E+11$ & 3.3 \\
\hline P10 & 0.00 & 5.99 & -23.85 & $3.229 E+11$ & $3.138 E+11$ & 2.8 \\
\hline P 8 & 10.30 & 5.99 & -23.85 & $3.100 E+11$ & $3.129 E+11$ & -0.9 \\
\hline P22 & -10.30 & 9.74 & -23.85 & $1.060 E+11$ & $1.031 E+11$ & 2.7 \\
\hline P19 & 0.00 & 9.74 & -23.85 & $1.689 E+11$ & $1.654 \mathrm{E}+11$ & 2.1 \\
\hline P16 & 10.30 & 9.74 & -23.85 & $1.587 E+11$ & $1.649 \mathrm{E}+11$ & -3.9 \\
\hline
\end{tabular}

Note: average deviation between adjusted and fitted value is $2.0 \%$; maximum deviation observed (at $P 14$ ) is $-6.3 \%$. 
Table A.6. Comparison of the adjusted fast fluence rates, $F_{E>0.1 \text { mev, with }}$ values obtained from three-dimensional (3-D) fit. Adjusted flux values are averages of the cycles 338B, 339B, and 340A

\begin{tabular}{|c|c|c|c|c|c|c|}
\hline \multirow[t]{2}{*}{ Location } & \multicolumn{3}{|c|}{ Coordinates } & \multicolumn{2}{|c|}{$F_{E>0.1 \mathrm{MoV}}$} & \multirow{2}{*}{$\begin{array}{c}\text { Difference } \\
(\%)\end{array}$} \\
\hline & $\begin{array}{c}X \\
(\mathrm{~cm})\end{array}$ & $\begin{array}{c}Y \\
(\mathrm{~cm})\end{array}$ & $\underset{(\mathrm{cm})}{Z}$ & $\begin{array}{l}\text { Adjusted } \\
\left(\mathrm{cm}^{-2} \mathrm{~s}^{-1}\right)\end{array}$ & $\begin{array}{l}\text { 3-D fitted } \\
\left(\mathrm{cm}^{-2} \mathrm{~s}^{-1}\right)\end{array}$ & \\
\hline P23 & -10.30 & 2.25 & 23.78 & $1.254 E+12$ & $1.240 E+12$ & 1.1 \\
\hline $\begin{array}{l}\text { P2 } \\
\text { P4 } \\
\text { P11 } \\
\text { P9 } \\
\text { P6 } \\
\text { P20 } \\
\text { P17 } \\
\text { P14 }\end{array}$ & $\begin{array}{r}0.00 \\
10.30 \\
-10.30 \\
0.00 \\
10.30 \\
-10.30 \\
0.00 \\
10.30\end{array}$ & $\begin{array}{l}2.25 \\
2.25 \\
5.99 \\
5.99 \\
5.99 \\
9.74 \\
9.74 \\
9.74\end{array}$ & $\begin{array}{l}23.78 \\
23.78 \\
23.78 \\
23.78 \\
23.78 \\
23.78 \\
23.78 \\
23.78\end{array}$ & $\begin{array}{l}2.027 E+12 \\
1.885 E+12 \\
8.018 E+11 \\
1.315 E+12 \\
1.124 E+12 \\
4.734 E+11 \\
7.770 E+11 \\
6.372 E+11\end{array}$ & $\begin{array}{l}2.052 E+12 \\
1.864 E+12 \\
7.664 E+11 \\
1.268 E+12 \\
1.152 E+12 \\
4.731 E+11 \\
7.828 E+11 \\
7.113 E+11\end{array}$ & $\begin{array}{r}-1.2 \\
1.1 \\
4.4 \\
3.6 \\
-2.5 \\
0.1 \\
-0.7 \\
-11.6\end{array}$ \\
\hline $\begin{array}{l}\text { P24 } \\
\text { P25 } \\
\text { P26 } \\
\text { P12 } \\
\text { P27 } \\
\text { P7 } \\
\text { P21 } \\
\text { P18 } \\
\text { P15 }\end{array}$ & $\begin{array}{r}-10.30 \\
0.00 \\
10.30 \\
-10.30 \\
0.00 \\
10.30 \\
-10.30 \\
0.00 \\
10.30\end{array}$ & $\begin{array}{l}2.25 \\
2.25 \\
2.25 \\
5.99 \\
5.99 \\
5.99 \\
9.74 \\
9.74 \\
9.74\end{array}$ & $\begin{array}{l}-0.03 \\
-0.03 \\
-0.03 \\
-0.03 \\
-0.03 \\
-0.03 \\
-0.03 \\
-0.03 \\
-0.03\end{array}$ & $\begin{array}{l}2.089 E+12 \\
3.483 E+12 \\
3.297 E+12 \\
1.378 E+12 \\
2.302 E+12 \\
1.981 E+12 \\
8.248 E+11 \\
1.371 E+12 \\
1.126 E+12\end{array}$ & $\begin{array}{l}2.148 E+12 \\
3.553 E+12 \\
3.229 E+12 \\
1.327 E+12 \\
2.196 E+12 \\
1.996 E+12 \\
8.195 E+11 \\
1.356 E+12 \\
1.232 E+12\end{array}$ & $\begin{array}{r}-2.8 \\
-2.0 \\
2.1 \\
3.7 \\
4.6 \\
-0.7 \\
0.6 \\
1.1 \\
-9.4\end{array}$ \\
\hline $\begin{array}{l}\text { P1 } \\
\text { P3 } \\
\text { P5 } \\
\text { P13 } \\
\text { P10 } \\
\text { P8 } \\
\text { P22 } \\
\text { P19 } \\
\text { P16 }\end{array}$ & $\begin{array}{r}-10.30 \\
0.00 \\
10.30 \\
-10.30 \\
0.00 \\
10.30 \\
-10.30 \\
0.00 \\
10.30\end{array}$ & $\begin{array}{l}2.25 \\
2.25 \\
2.25 \\
5.99 \\
5.99 \\
5.99 \\
9.74 \\
9.74 \\
9.74 \\
\end{array}$ & $\begin{array}{l}-23.85 \\
-23.85 \\
-23.85 \\
-23.85 \\
-23.85 \\
-23.85 \\
-23.85 \\
-23.85 \\
-23.85\end{array}$ & $\begin{array}{l}9.556 \mathrm{E}+11 \\
1.559 \mathrm{E}+12 \\
1.461 \mathrm{E}+12 \\
6.202 \mathrm{E}+11 \\
1.027 \mathrm{E}+12 \\
8.852 \mathrm{E}+11 \\
3.707 \mathrm{E}+11 \\
6.142 \mathrm{E}+11 \\
5.047 \mathrm{E}+11\end{array}$ & $\begin{array}{l}9.610 \mathrm{E}+11 \\
1.590 \mathrm{E}+12 \\
1.445 \mathrm{E}+12 \\
5.940 \mathrm{E}+11 \\
9.828 \mathrm{E}+11 \\
8.930 \mathrm{E}+11 \\
3.667 \mathrm{E}+11 \\
6.067 \mathrm{E}+11 \\
5.513 \mathrm{E}+11\end{array}$ & $\begin{array}{r}-0.6 \\
-2.0 \\
1.1 \\
4.2 \\
4.3 \\
-0.9 \\
1.1 \\
1.2 \\
-9.2\end{array}$ \\
\hline
\end{tabular}

Note: average deviation between adjusted and fitted value is $2.9 \%$; maximum deviation observed (at $\mathrm{P} 14$ ) is $-11.6 \%$. 
Table A.7. Comparison of the adjusted displacement-per-atom (dpa) rates with values obtained from three-dimensional (3-D) fit. Adjusted dpa rates are averages of the cycles 338B, 339B, and 340A

\begin{tabular}{|c|c|c|c|c|c|c|}
\hline \multirow[t]{2}{*}{ Location } & \multicolumn{3}{|c|}{ Coordinates } & \multicolumn{2}{|c|}{ dpa rate } & \multirow{2}{*}{$\begin{array}{l}\text { Difference } \\
(\%)\end{array}$} \\
\hline & $\underset{(\mathrm{cm})}{X}$ & $\begin{array}{c}Y \\
(\mathrm{~cm})\end{array}$ & $\underset{(\mathrm{cm})}{Z}$ & $\begin{array}{c}\text { Adjusted } \\
\left(\mathbf{s}^{-1}\right)\end{array}$ & $\begin{array}{c}\text { 3-D fitted } \\
\left(s^{-1}\right)\end{array}$ & \\
\hline $\begin{array}{l}\text { P23 } \\
\text { P2 } \\
\text { P4 } \\
\text { P11 } \\
\text { P9 } \\
\text { P6 } \\
\text { P20 } \\
\text { P17 } \\
\text { P14 }\end{array}$ & $\begin{array}{r}-10.30 \\
0.00 \\
10.30 \\
-10.30 \\
0.00 \\
10.30 \\
-10.30 \\
0.00 \\
10.30\end{array}$ & $\begin{array}{l}2.25 \\
2.25 \\
2.25 \\
5.99 \\
5.99 \\
5.99 \\
9.74 \\
9.74 \\
9.74\end{array}$ & $\begin{array}{l}23.78 \\
23.78 \\
23.78 \\
23.78 \\
23.78 \\
23.78 \\
23.78 \\
23.78 \\
23.78\end{array}$ & $\begin{array}{l}7.410 \mathrm{E}-10 \\
1.174 \mathrm{E}-09 \\
1.143 \mathrm{E}-09 \\
4.244 \mathrm{E}-10 \\
6.797 \mathrm{E}-10 \\
6.163 \mathrm{E}-10 \\
2.340 \mathrm{E}-10 \\
3.746 \mathrm{E}-10 \\
3.304 \mathrm{E}-10\end{array}$ & $\begin{array}{l}7.298 \mathrm{E}-10 \\
1.180 \mathrm{E}-09 \\
1.136 \mathrm{E}-09 \\
4.111 \mathrm{E}-10 \\
6.650 \mathrm{E}-10 \\
6.398 \mathrm{E}-10 \\
2.312 \mathrm{E}-10 \\
3.740 \mathrm{E}-10 \\
3.599 \mathrm{E}-10\end{array}$ & $\begin{array}{r}1.5 \\
-0.6 \\
0.6 \\
3.1 \\
2.2 \\
-3.8 \\
1.2 \\
0.2 \\
-8.9\end{array}$ \\
\hline $\begin{array}{l}\text { P24 } \\
\text { P25 } \\
\text { P26 } \\
\text { P12 } \\
\text { P27 } \\
\text { P7 } \\
\text { P21 } \\
\text { P18 } \\
\text { P15 }\end{array}$ & $\begin{array}{r}-10.30 \\
0.00 \\
10.30 \\
-10.30 \\
0.00 \\
10.30 \\
-10.30 \\
0.00 \\
10.30\end{array}$ & $\begin{array}{l}2.25 \\
2.25 \\
2.25 \\
5.99 \\
5.99 \\
5.99 \\
9.74 \\
9.74 \\
9.74\end{array}$ & $\begin{array}{l}-0.03 \\
-0.03 \\
-0.03 \\
-0.03 \\
-0.03 \\
-0.03 \\
-0.03 \\
-0.03 \\
-0.03\end{array}$ & $\begin{array}{l}1.187 \mathrm{E}-09 \\
1.936 \mathrm{E}-09 \\
1.921 \mathrm{E}-09 \\
7.002 \mathrm{E}-10 \\
1.142 \mathrm{E}-09 \\
1.046 \mathrm{E}-09 \\
3.917 \mathrm{E}-10 \\
6.363 \mathrm{E}-10 \\
5.616 \mathrm{E}-10\end{array}$ & $\begin{array}{l}1.214 \mathrm{E}-09 \\
1.963 \mathrm{E}-09 \\
1.889 \mathrm{E}-09 \\
6.837 \mathrm{E}-10 \\
1.106 \mathrm{E}-09 \\
1.064 \mathrm{E}-09 \\
3.845 \mathrm{E}-10 \\
6.220 \mathrm{E}-10 \\
5.984 \mathrm{E}-10\end{array}$ & $\begin{array}{r}-2.2 \\
-1.4 \\
1.7 \\
2.4 \\
3.2 \\
-1.7 \\
1.8 \\
2.3 \\
-6.6\end{array}$ \\
\hline $\begin{array}{l}\text { P1 } \\
\text { P3 } \\
\text { P5 } \\
\text { P13 } \\
\text { P10 } \\
\text { P8 } \\
\text { P22 } \\
\text { P19 } \\
\text { P16 }\end{array}$ & $\begin{array}{r}-10.30 \\
0.00 \\
10.30 \\
-10.30 \\
0.00 \\
10.30 \\
-10.30 \\
0.00 \\
10.30\end{array}$ & $\begin{array}{l}2.25 \\
2.25 \\
2.25 \\
5.99 \\
5.99 \\
5.99 \\
9.74 \\
9.74 \\
9.74\end{array}$ & $\begin{array}{l}-23.85 \\
-23.85 \\
-23.85 \\
-23.85 \\
-23.85 \\
-23.85 \\
-23.85 \\
-23.85 \\
-23.85\end{array}$ & $\begin{array}{l}5.499 \mathrm{E}-10 \\
8.791 \mathrm{E}-10 \\
8.622 \mathrm{E}-10 \\
3.201 \mathrm{E}-10 \\
5.182 \mathrm{E}-10 \\
4.747 \mathrm{E}-10 \\
1.791 \mathrm{E}-10 \\
2.898 \mathrm{E}-10 \\
2.561 \mathrm{E}-10\end{array}$ & $\begin{array}{l}5.508 \mathrm{E}-10 \\
8.908 \mathrm{E}-10 \\
8.571 \mathrm{E}-10 \\
3.103 \mathrm{E}-10 \\
5.018 \mathrm{E}-10 \\
4.828 \mathrm{E}-10 \\
1.745 \mathrm{E}-10 \\
2.823 \mathrm{E}-10 \\
2.716 \mathrm{E}-10\end{array}$ & $\begin{array}{r}-0.2 \\
-1.3 \\
0.6 \\
3.1 \\
3.2 \\
-1.7 \\
2.6 \\
2.6 \\
-6.0\end{array}$ \\
\hline
\end{tabular}

Note: average deviation between adjusted and fitted value is $2.5 \%$; maximum deviation observed (at $\mathrm{P} 14$ ) is $-8.9 \%$. 


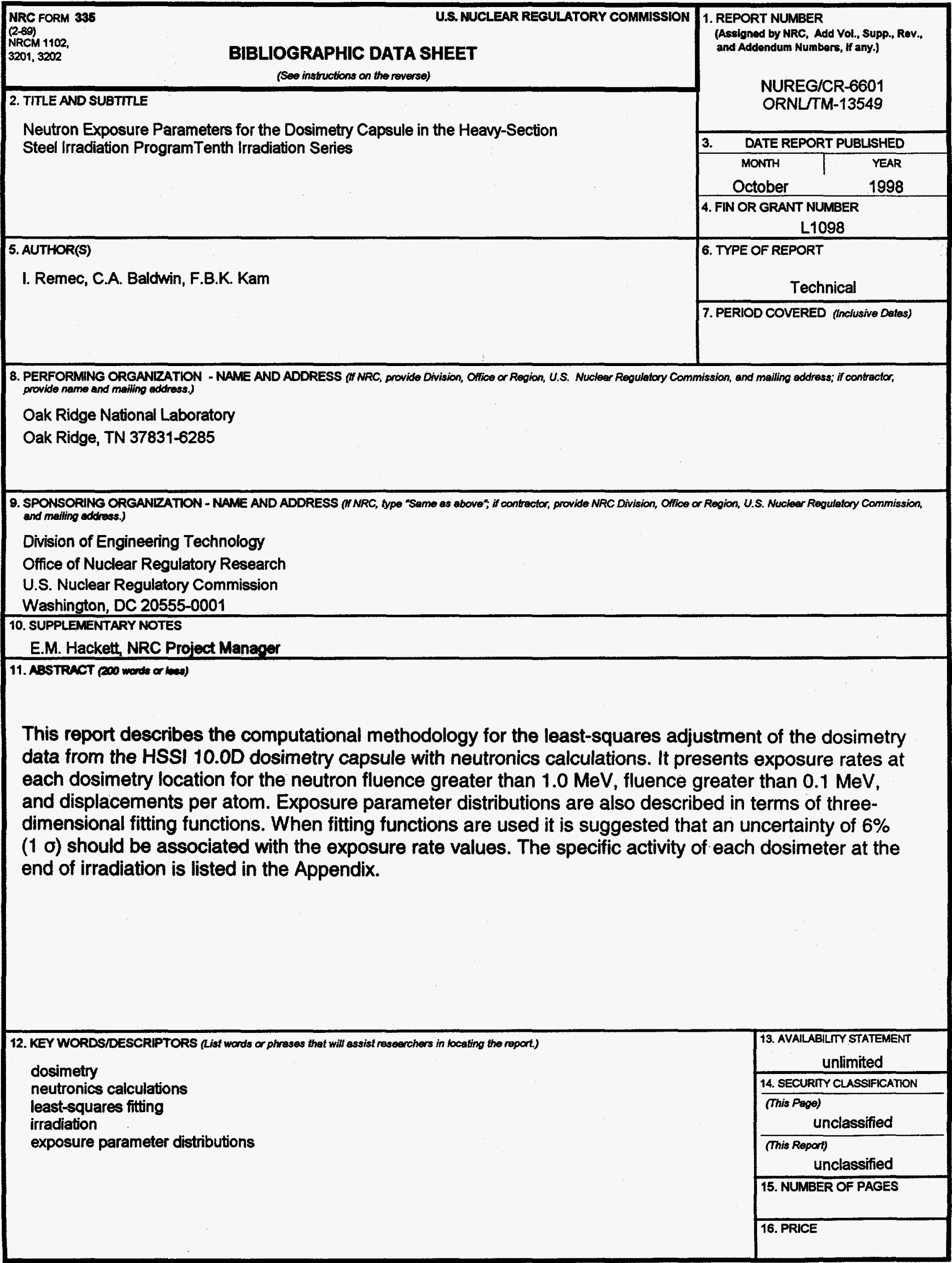

